\title{
The Islamic Port of al-Balìd (Oman), between Land and Sea: Place of Trade, Exchange, Diversity, and Coexistence
}

\author{
Agnese Fusaro \\ ERAAU B Team, University of Barcelona, Spain \\ agnese.fusaro@gmail.com
}

\begin{abstract}
The site of al-Balīd (Southern Oman), identified as the ancient Zafār, was a major port city in the Islamic period. Its strategic position and its history, strongly interdependent with that of neighbouring regions, gave it an important socio-economic role.

The abundant ceramics and the rich and diverse archaeological materials recovered at the site prove that al-Balīd has always maintained relationships with people living inland and, at the same time, that it was intensively involved in the Indian Ocean trade. The pottery also reflects the coexistence of different traditions, various social classes, and several communities at al-Balīd.
\end{abstract}

\section{Keywords}

al-Balīd - Zafār - pottery - Islamic period - interregional relationships - Indian Ocean trade communities' coexistence

\section{Introduction}

This paper ${ }^{1}$ presents the results of the recent archaeological project on the site of al-Balid, with a particular focus on the study of pottery and the insights into the historical, economic and social aspects it offers. ${ }^{2}$

The Islamic site of al-Balīd is located in the Dhofar region, the southern Governorate of present-day Oman (Fig. 1). It is the largest and most visited archaeological site of Southern Oman, especially after being declared UNEsco World Heritage in 2000. Its fame was even greater in the past, as suggested by the dimensions of the walled site and the richness of the materials found.

Al-Balīd was identified as the ancient port city of Zafār mentioned in the accounts of travellers such as Ibn al-Mujāwir (1204/5-91), Marco Polo (1254-1324), and Ibn Bațțutạa (1304-68/9 or 1304-77), but also in Chinese sources (see below). It was one of the main centres in the so-called Frankincense Land. Moreover, at least since the thirteenth century, Zafär played a crucial role in the Indian Ocean trade network. The Dhofar region is influenced by monsoons, which makes trade over sea much easier than trade over land. For a long time, trade was the most important activity for the city, as testified by Ibn Battūtata, who wrote that the inhabitants were merchants who lived entirely from trade (Defremery and Sanguinetti, 1969: 198). Many goods were exported, imported, or passed 
through Zafär. During the Islamic period, its involvement in the trade facilitated the development of the city (Staples, 2017: 106; Newton and Zarins, 2014: 269-270).

\section{$2 \quad$ Historical Background}

Zafār was under the dominion of different dynasties: the Manjū/Manjawiyyūn rulers that some scholars thought to be Persian (Guest, 1935: 403), possibly from Sīrāf; the Habūdī dynasty (1203-79), probably originally from Hadramawt (Guest, 1935: 403), according to several historians, under this dynasty Zafār was destroyed in 1221, and a new city called al-Manșurā was reconstructed (Smith, 1985: 83); the Rasūlids of Yemen (1279-1420), which transformed Zafār into an important port along the trade route to the Persian Gulf and India (Guest, 1935: 407); the Kathīrī family of Hadramawt (midfifteenth-mid-seventeenth centuries, Smith, 2005: 413). When the Portuguese and the Ottomans arrived in the sixteenth century, the city progressively decayed. Nonetheless al-Balīd was able to recover, reaching certain prosperity in the seventeenth-eighteenth centuries, before it collapsed and was completely abandoned.

During the Habūdī period, Zafār acquired a significant role in the Indian Ocean trade network. This was also the result of the general political situation (that is the fall of the 'Abbasids and the Būyids, and the decline of Șuhārr in the north) that caused the shift of trade from the Persian Gulf to the Red Sea, and further south, also involving Oman and Yemen (Staples, 2017: 83, 98).

Particularly from the thirteenth century onward, the city greatly flourished (Guest, 1935: 407), as it was integrated into a growing and extremely active Yemeni trade network developed by the Rasūlids, involving Arabia, India, and Africa (Staples, 2017: 106; Guest, 1935: 407). Trade constituted the principal source of income for the Rasūlids; consequently, the merchants became a powerful and rich social class, comprising not only Yemeni and Omani merchants, but also Indians, Egyptians and Africans (Guest, 1935: 407). There must have been a similar social situation in Zafār, as this city was strongly influenced by the political decisions of the Rasūlids (Varisco, 1993: 19).

Different travellers confirmed the splendour and the key role of Zafār as a port. Marco Polo visited the city in 1290 and highlighted its important role in one of the most profitable trades of the period: that of horses. The animals were gathered inland (mountains and inner deserts), but also on the islands, and were collected in several ports, including Zafār; the merchants sold them in India, as the horses were particularly appreciated by the Indian rulers between the thirteenth and the fifteenth centuries. Some years later (in 1329), Ibn Batțutata reported how much this trade had flourished (Defremery and Sanguinetti, 1969: 196). Besides the horses, Zafär and the region were also known for the export of frankincense and dried sardines, used primarily for the feeding of animals (Defremery and Sanguinetti, 1969: 196-197; Smith, 1985: 85). In Chinese sources of the thirteenth to the fifteenth centuries, Zafär and the whole coast of Dhofar are mentioned as centres of export for local products, such as frankincense, ambergris, pearls, myrrh, dragon's blood, aloes, benzoin, liquid storax, camels and ostriches, but also as a place of distribution for goods arriving from Africa, such as rhino horns and ivory. Most of these items were brought to China and exchanged for silk and porcelains (Pavan and Visconti, 2020: 243-245). 


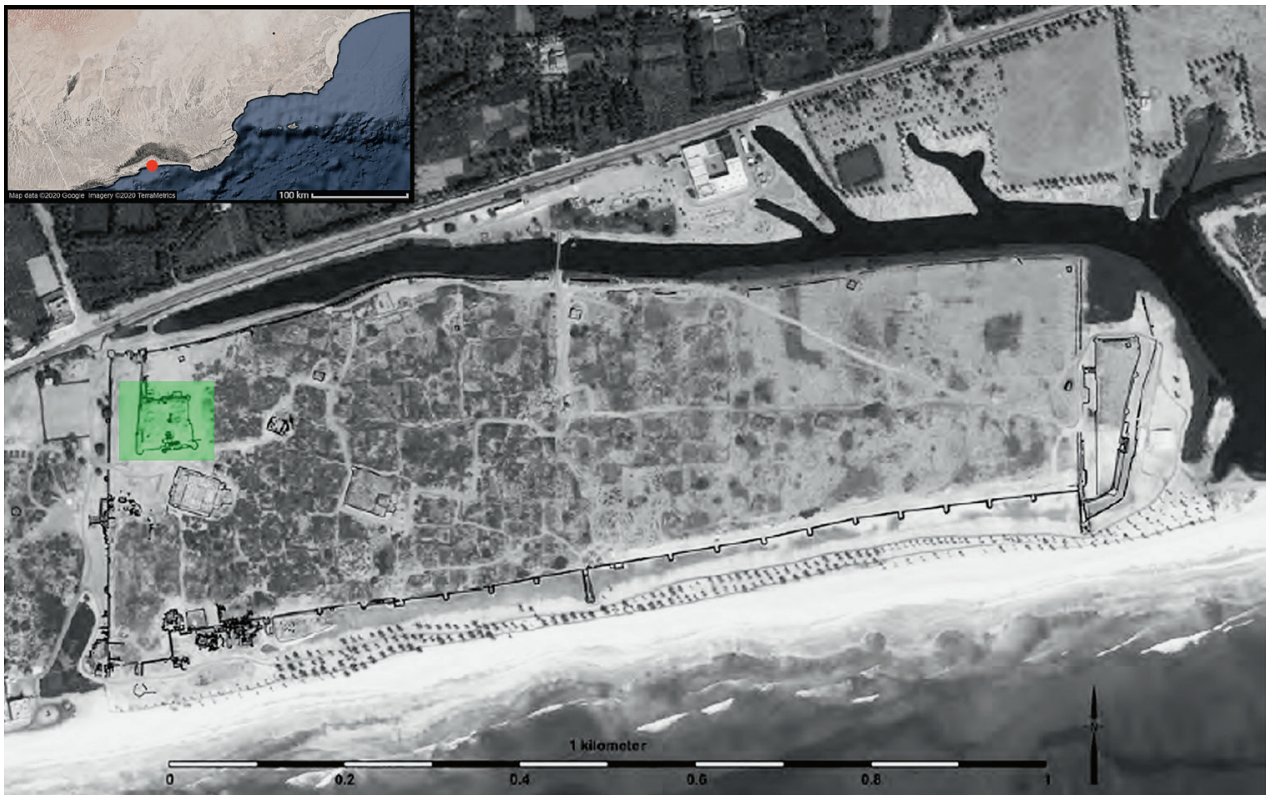

\section{Archaeological Research}

The archaeological site of al-Balīd lies in the Șalālah plain, $5 \mathrm{~km}$ east of the modern city, at the culmination of a major river system, providing abundant fresh water to the area. The site consists of a large fortified city just on the Ocean littoral (Fig. 1); larger suburbs with agricultural fields and artisanal workshops existed to the north, while a marketplace and a large cemetery were located to the west. The western part of the fortified site was the most important one: it hosts the Husn, the fortified palace, a large congregational mosque, and a customs house. Mosques, large houses, and a marketplace were located in the central part; in the southern part there were the jetties, the dockyard, and buildings for the arrival and registration of items; the eastern part could have been used for storing and preparing goods.

The Husn ${ }^{3}$ was built on a higher plane, thus appearing as the most prominent complex of the site (Fig. 2). It is roughly square in plan, covering a surface of almost 5,000 sqm. It has been interpreted as the residence of the local ruler. It was a multi-storey building, with four levels in the last occupation phases. It has massive walls with circular towers. The main point of access was the southern gate, which directly connects the palace with the congregational mosque; a western and an eastern gate have also been identified. Parts of the ceilings with the original wooden beams are still preserved in some areas. An extension along the northern side has been interpreted as the bathroom drains of the Husn. Leaning just against the east perimeter wall of the building, a series of rooms have been recently brought to light and identified as horses' stables (Pavan in Pavan et al., 2018: 212).

After the publication of accounts of European travellers that provided information on the site (for an overview, see Tkatsch, 1934: 1256), from 1930 onward, al-Balīd started to be archaeologically investigated; several missions conducted surveys, excavations, topographical works, and restoration activities until 2012. ${ }^{4}$ The excavations were resumed in 2016, along with the consolidation of the exposed structures and the study of the materials, under the direction of Alexia Pavan (archaeological consultant for the Omani Office of the Adviser to His Majesty the Sultan for Cultural Affairs), and they concentrate on the Husn (Pavan et al., 2018). ${ }^{5}$
FIGURE 1

Aerial photograph of the site of al-Balīd with the indication of the Husn (after Al Baleed Archaeological Park Salalah 2014: 87); top, left: the Dhofari coast with the site of al-Balīd (C) GOOGLE 
Besides ceramics, which are the most abundant findings, a remarkable quantity of rich and varied materials has been collected and comprises: glass bracelets, glass vessels, incense burners, numerous coins, war devices, such as cannonballs, mangonels, arrowheads, and, particularly worth mentioning, numerous ship timbers reemployed as architectural components. The study of all these materials is carried out by several researchers (Pavan et al., 2018); the final matching of collected data will provide comprehensive overviews of the products traded according to the regions with which al-Balīd was in contact, and of the dynamics of supply and demand of specific items.

Between 2016 and 2018, a research project on the study of the pottery from the Husn was carried out by the present author, in parallel with the excavations. ${ }^{6}$ It has a multidisciplinary approach: the archaeological study is supported by archaeometric analyses and an ethnoarchaeological work on modern Dhofari production.

Especially the study of pottery allows the establishment of solid chronological phases and contributes to shedding new light on several historical and socio-economic issues. Primary purposes of this study are: matching the phases of the Husn with relevant historical events, retracing the history of al-Balīd, and finally integrating it into the broader history of the Indian Ocean; investigating the relations between al-Balid and other minor sites in Dhofar; recognizing trade patterns and the commercial role of al-Balìd, and their changes throughout the centuries; identifying the presence of communities of foreigners that settled in the city.

Husn: Chronological Phases

As shown in the plan of the Husn (Fig. 2), the new archaeological investigations explore a large number of contexts, located in different areas of the fortified palace, both inside and outside the walls. So far, the pottery study has concentrated on the findings from several selected contexts: rooms $\mathrm{A}_{31}$ and $\mathrm{A}_{33}$, and the larger room underneath; room $\mathrm{A}_{2}$ and the room underneath, just behind the southern entrance; room A5, just behind the south-eastern corner tower; the central-eastern area; a trench in the central-southern area; a sequence of rooms $\left(\mathrm{A}_{52}{ }^{-} \mathrm{A} 57\right)$ leaning against the eastern perimeter wall of the Husn, interpreted as horses' stables; and the eastern gate in the same perimeter wall. ${ }^{7}$

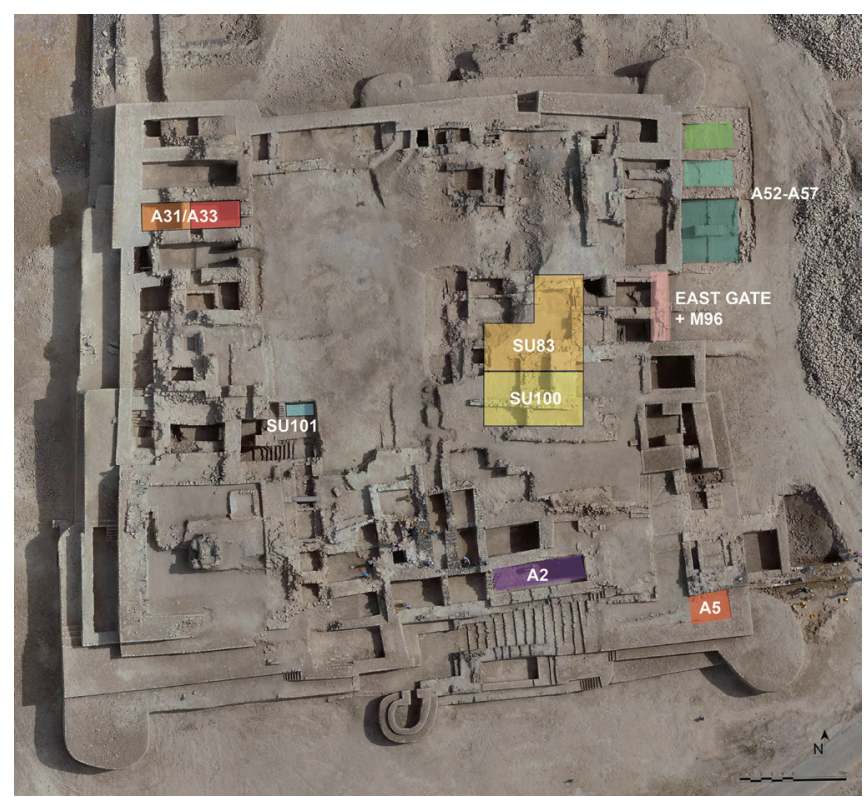

FIGURE 2

Orthophotograph of the Husn, with indication of the archaeological contexts selected for the pottery study

(C) A. MASSA, ESPLORATIVA ARCHITETTI; MODIFIED BY A. FUSARO 
The preliminary analysis of the ceramic assemblages allows the establishment of a sequence for the areas investigated, suggesting at least three main phases. They correspond to the last three (IV, V, and VI) of the six constructional phases of the Husn, ${ }^{8}$ identified on the basis of the results of the excavations conducted so far, including the current ones, the analysis of the masonries, and the study of the archaeological materials (Pavan in Pavan et al., 2018: 213-216).

In the thirteenth-fourteenth centuries, the Husn reached its largest size. The rooms of the lower floor of the building and the horses' stables were in use. The southern entrance of the palace was the most important section, and the associated monumental staircase was built in the fourteenth century. According to archaeological data, the eastern gate was in use during the Habūdī period. The architecture was exclusively made from large and massive cut stone blocks. This monumental phase (Phase IV, 1279-1500) can be associated with the Rasūlid period: the city's government, nominally under the Yemeni dynasty, was de facto independent (Tkatsch, 1934: 1256; Guest, 1935: 404-405; Smith, 1988: 32) and greatly flourished.

Since the fifteenth century, during the constructional Phase V (1500-1650), the stables and possibly parts of the northern area were intentionally obstructed by ramparts built on accumulations of stones and debris; the eastern entrance of the palace was also closed. Some rooms on the lower floors, placed along the curtain wall of the Husn, were filled. These changes were part of a more comprehensive transformation that, together with the addition of bastions, towers, buttresses, and casemates along all the four sides, aimed at strengthening the defensive system. Moreover, around the fifteenth-sixteenth centuries, one room on the second floor was probably used for the production of gunpowder and other weapons. This archaeological phase can be related to the rule of the Kathīrī dynasty, that had to face the attacks of both the Portuguese and the Ottomans.

The seventeenth-eighteenth centuries are the latest occupational phase of the Husn, corresponding to Phase vi (1650-1800). This phase could be extended to the end of the eighteenth and even the beginning of the nineteenth centuries, thanks to the new data provided by the ongoing archaeological research-work. New, rather poor structures were built on the third and fourth floors of the western part of the palace. They were made of bricks walls covered with plaster. Their presence seems to have been reported by the Portuguese Jesuits, who saw "poor mud buildings which they [the citizens] regarded as a fort" (Beckingham and Serjeant, 1950: 195). The remains of a tank in the south-western corner of the Husn also belong to this period, along with a plastered floor that was used as a foundation for a number of plastered basins.

The collapse of many stone walls of the palace suggests its final abandonment.

\section{5}

\section{The Pottery Corpus}

The ceramic corpus, collected at the Husn of al-Balīd, and studied between 2016 and 2018 , totals about 13,000 items. It mostly consists of local productions; there are also regional manufactures and a striking quantity of imports.

\section{Local Wares: Conservatism and Continuity of the Tradition}

The local wares (Figs. 3-6) share common features that can be considered typical for the local tradition until the modern era. All vessels are unglazed and hand-made, some have probably been shaped with the slabbing or coiling technique, the spherical vessels were possibly produced with the aid of a simple former. The most common surface 
FIGURE 3

Specimens of the shell temper ware collected at the Husn: a. large pot inv.no. 22,288; b. jug inv.no. 100,26

DRAWINGS AND PHOTOS C A. FUSARO

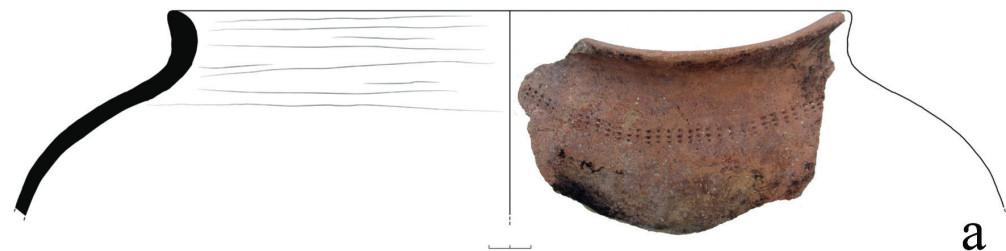

a

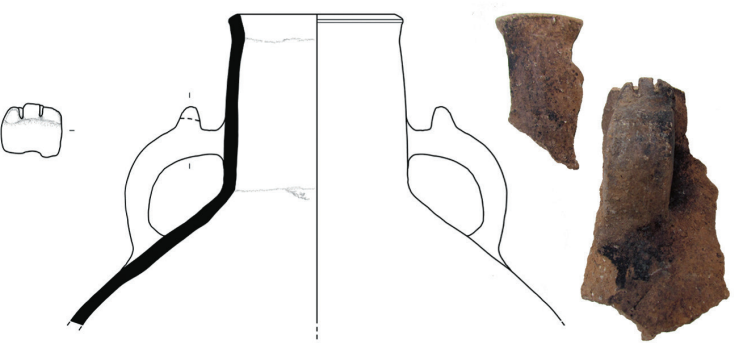

b

treatments are smoothing and burnishing. Red paint, simple incisions, and finger impressions are common decorations; incised and impressed motifs were also made with the use of a comb, or, more rarely, with a shell. Almost all vessels were fired using an open-firing technique. The local wares were probably produced in the Șalālah plain or immediately inland; 9 according to the information given by modern women potters, the possible clay sources can be found near Ṭawī Attīr (Ṭāqah) or in the area of Șalālah al-Wusțâ, located at a distance from the site of al-Balìd of 11,30 hours and 1,20 hours by foot, respectively. ${ }^{10}$

Despite the simplicity, both of techniques and fashion, the local potters show exceptional skills, and in specific historical periods (especially in the seventeenth-eighteenth centuries) they were able to produce high-quality and fine vessels.

Within the local production, four main groups have been identified and outlined, mainly according to the features of the ceramic bodies and the function of the vessels.

The shell temper ware primarily consists of cooking pots and jars, frequently without any surface finishing, sometimes bearing simple or comb-impressed decoration (Fig. 3.a); the finer variant comprises small storage containers, jugs, also spouted (Fig. 3.b), and small bowls probably used as tableware.

The grit temper ware can be considered kitchenware; bowls, basins, pots, jars, large trays that are mostly related to the preparation of food, sometimes in relation to heating (Fig. 4.a), but there are also storage vessels (Figs. 4.e-f); if present, the decoration is painted in red (Figs. 4.c-d). The better-finished vessels could have been used for serving food (Fig. 4.b).

The red ware is the proper tableware, comprising fine bowls, dishes, jugs, jars, and a few pots, usually of small dimensions; some jars could have also been used for storage; the surfaces always show a well-made finish, the most refined are polished and red slipped (Figs. 5.b-c), and frequently bear painted decorations (Fig. 5.a).

The dot-and-circle ware is unique and characteristic for the Dhofar region. The name is derived from the principal motif stamped on the vessels: a dot in a circle (Fig. 6.a). This motif is common in productions of different materials spread through the whole Arabian Peninsula, and the Iranian-Iraqi regions since the Bronze Age. However, only in Dhofar the motif started to be used on pottery, with a beginning proposed between the fourth and the sixth centuries A.D. (Sedov and Benvenuti, 2002: 199; Newton and Zarins, 2010: 254; Newton and Zarins, 2017: 89). The uniqueness of this ceramic production lies in its longevity, as it was in circulation until the fourteenth-fifteenth centuries and bore a very ancient motif until the modern era, ${ }^{11}$ in its well-delimited manufacturing area, 


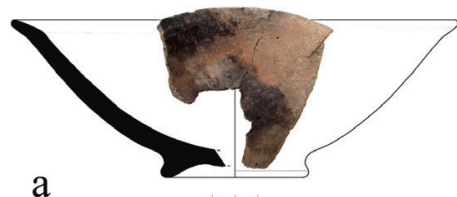

a
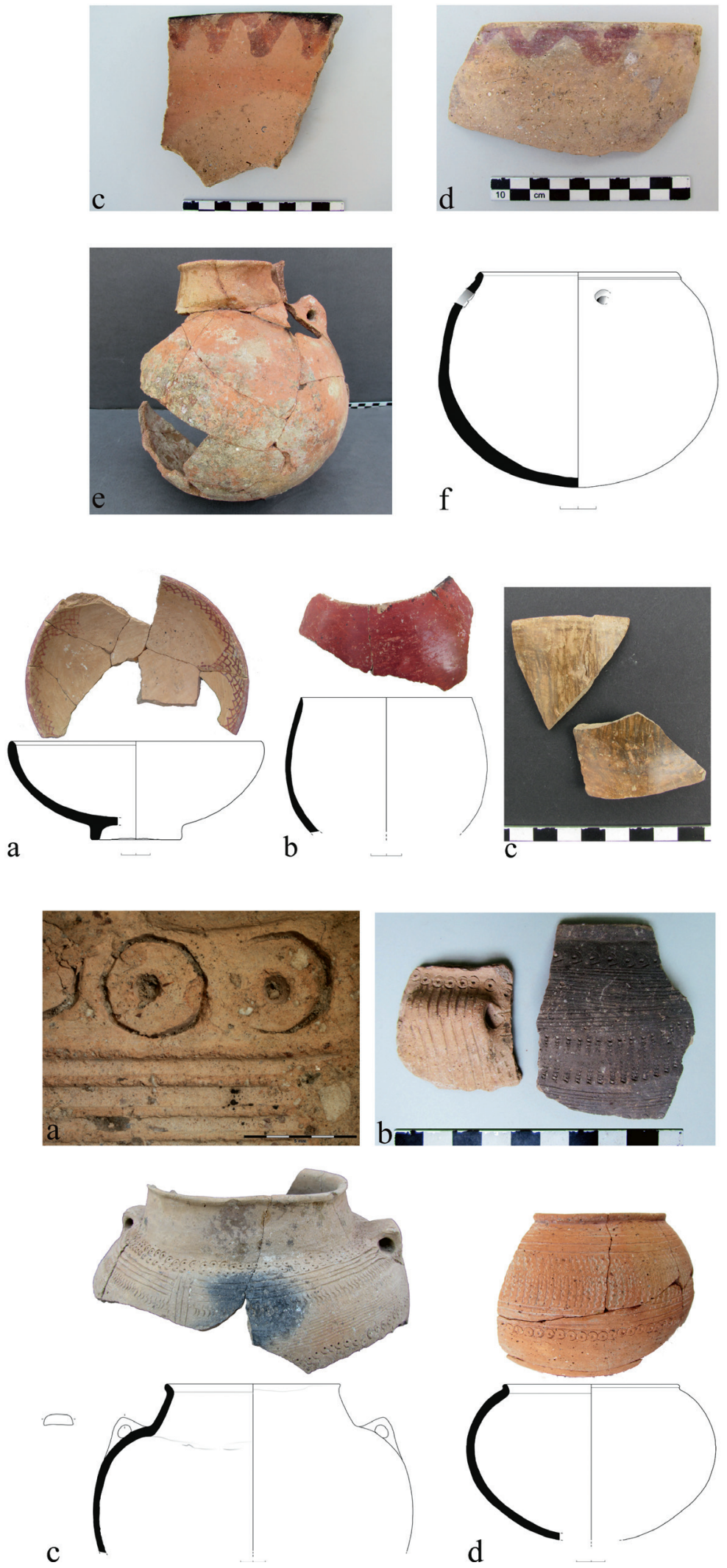

FIGURE 4

Specimens of the grit temper ware collected at the Husn: a. bowl inv. no. $73 \mathrm{LW}, 54$; b. small bowl inv.no. 83,2; c-d. painted bowls inv.nos. 61,81 and 61,91 ; e. handled jar inv. no. 48,1 ; f. pot inv.no. 73,42 DRAWINGS AND PHOTOS (C) A. FUSARO

FIGURE 5

Specimens of the red ware collected at the Husn: a. bowl inv.no. 22,39; b. inturned bowl inv.no. 22,54; c. jug inv.no. 22,162 DRAWINGS AND PHOTOS (C) A. FUSARO

FIGURE 6

Specimens of the dot-and-circle ware collected at the Husn: a. microphotograph of the decoration of sample ASBA29 from the room underneath A31/A33; b. two fragments from room A2; c. handled jar inv.no. 73L,48; d. pot inv.no. 43,59 DRAWINGS AND PHOTOS (C) A. FUSARO 
FIGURE 7

Items belonging to the regional grit ware from the Husn: a. handled jar inv.no. 22,41 that details of the decoration; $b$. spouted bowl inv.no. 22,461; c. modern item produced at the Women Association in Țāqah PHOTOS (C) A. FUSARO

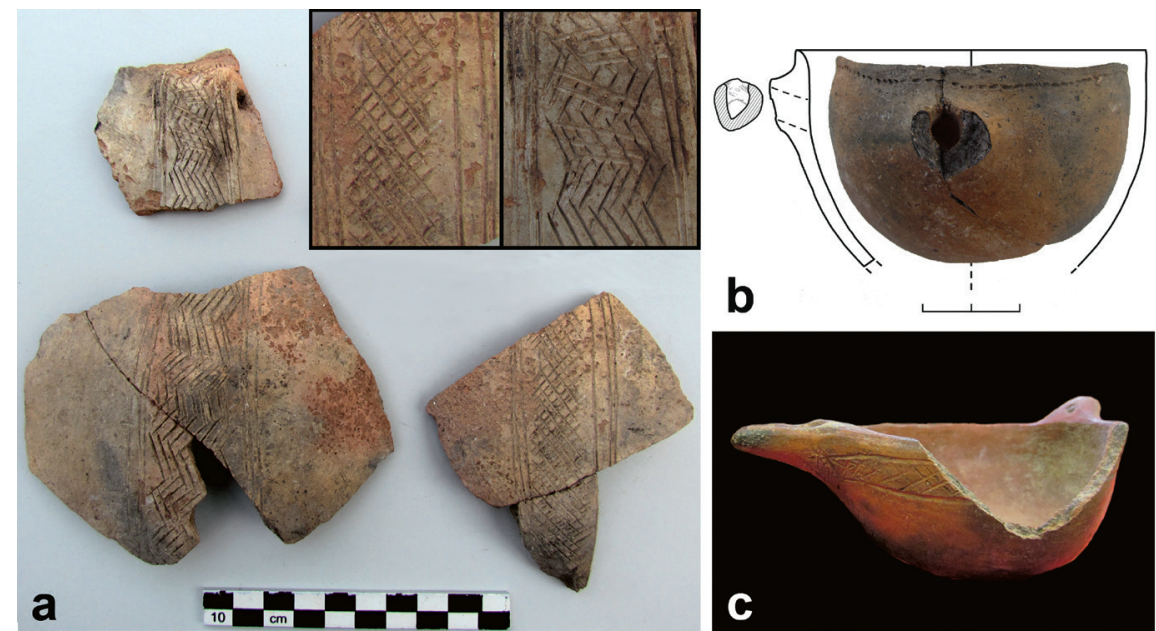

as it is indigenous to Dhofar, and was undoubtedly also produced on the Șalālah plain. The specimens found at the Husn are inturned bowls, globular pots, and handled jars (Figs. 6.c-d). The dot-and-circle motif is frequently associated with shell- or combimpressions, incisions, and even red paint (Fig. 6).

One of the most remarkable features of the local production is its conservatism. Although the population of al-Balīd received numerous external stimuli, both in terms of the circulation of imported ceramics and communities of foreigners living alongside local people (see below), the few and simple shaping, finishing, decorative and firing techniques that characterize it since the beginning, were maintained, perpetuated, and transmitted throughout the Islamic period up to the present day.

To examine the longevity of the local tradition, the author conducted a parallel ethnoarchaeological research into modern traditional pottery production in Dhofar. This research consisted of interviews with local women and visits to workshops in Șalālah, Ṭāqah, and Mirbāț, documenting and collecting information on the whole manufacturing process. Two women were interviewed extensively in November 2017 and April 2018: Fatima Salima Jebel who made pottery in the past, within a household production context; Amina Fatallah al-Farid who still produces ceramics in the Salalah Handicraft Center. We also visited the Omani Women Association of Mirbāt, and the Women Association in Țāqah, and we had a chance to talk to the eldest women, including the president of the Tāqah Association, Fatima Obeyd Amri, and the potter Tuful Sayyd Sohil al-Mashani.

Besides giving more information on the past manufacturing process, the ethnoarchaeological work can contribute to the examination of continuity and changes of pottery handicrafts, as well as phenomena of knowledge transfer, throughout the centuries up to the modern era, before the local ceramic tradition completely changes in fashion and technology or even disappears. Indeed, in all the workshops visited so far, only the older ladies still remember the traditional way of making pottery, while the younger women are losing the memory of this tradition. Furthermore, differences among workshops and areas within Dhofar are disappearing, as they are progressively innovating and homogenizing manufacturing techniques. ${ }^{12}$ In many cases women use gypsum moulds to produce items in an 'industrial' way. At the same time, imported pottery competes with traditional products (Almamari, 2017). 
As mentioned above, the trade in horses and frankincense was essential for the richness of Zafār. The demand for the best-quality goods led the city to establish relationships with tribes living inland, as well as other coastal settlements. Throughout the Islamic period, the city maintained long-lasting relationships with many different groups in Dhofar and neighbouring lands, from the mountains and the desert to the islands (Zarins and Newton, 2017a: 77-81); these relationships guaranteed people access to resources and safety on the routes (Newton and Zarins, 2010: 248) that sometimes became dangerous and impracticable (Smith, 1985: 84; Zarins and Newton, 2017a: $67-70)$. The patterns of this inland-coastal network, in the form of both conflicts and interchanges, have often influenced the history of al-Balìd.

The study of the pottery sheds new light onto this still largely unknown topic, giving insights into the neighbouring communities with which al-Balid had short-range contacts. Indeed, a distinct small group of vessels recovered at the Husn has been interpreted as regional manufactures. They resemble the local wares in many ways, thus suggesting a similar tradition, but they are made of different fabrics, produced from raw materials that may originate from other supply areas, and whose recipes changed. The similarities may suggest that they belong to a regional production, possibly localized in Dhofar or adjacent regions, but not on the Șalālah plain, as the raw materials are different.

The regional grit ware comprises inturned bowls and jars, which frequently show burnished surfaces; the decoration consists of incisions and impressed notches (Figs. 7.a-b); they closely resemble the local red ware and even modern production (Fig. 7.c). These vessels have been recovered in layers dated to the fourteenth-fifteenth centuries.

Another small group of unglazed hand-made globular pots has been found in layers dated to the same period (Figure 8). Some were used as cooking vessels (Figure 8.a). Its well-distinguishable fabric has a soapy feeling and a high amount of shiny flakes, possibly chlorite or steatite. According to the geological nature of these inclusions, this ware could have been produced in Southern Arabia (Pavan, 2017:30-31), more specifically in Yemen (Porter, 2018), Eastern Oman (David-Cluny, 2001: 319-324), or on Mașīrah island (Rollinson, 2017). On the latter, Zarins and Newton reported having found items belonging to this ware (Zarins and Newton, 2017b: 103). The same authors also proposed an origin in the area of Mirbāt (Newton and Zarins, 2017: 88).

\section{Imports: al-Balīd and the Indian Ocean Trade Network}

At least from the fourteenth until the eighteenth centuries onward, abundant and diverse ceramic imports circulated continuously at the site, as testified by the findings collected in all the assemblages examined from the Husn, in total $8.5 \%$ of the whole pottery corpus. They come from different lands, ranging from the Arabian Peninsula to as far China and South-East Asia. ${ }^{13}$ Below a selection of them will be presented, especially a few that can be related to historical events, and that raise the most interesting socio-economic issues.

The analysis of the imports within the stratigraphy and the variation of their proportions in the archaeological phases lead to a reconstruction of the trade relations established between al-Balīd and other lands throughout the centuries; it also clarifies

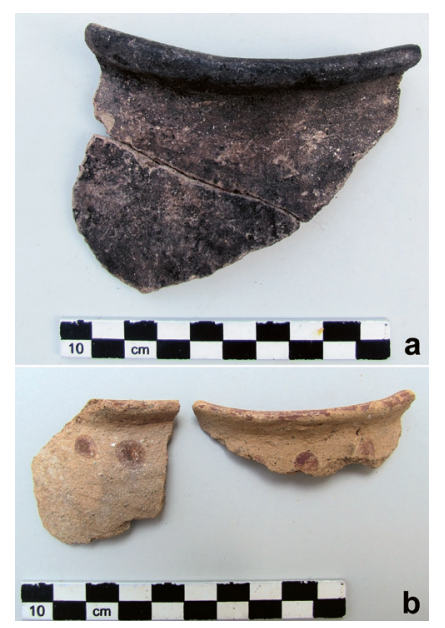

FIGURE 8

Items belonging to the flakes-temper ware from the Husn: a. cooking pot inv.no. 43,66; b. painted pot inv.no. $73 \mathrm{~L}, 16$ PHOTOS (C) A. FUSARO 
FIGURE 9

Chinese imports found at the Husn: celadon jar inv.no. 18,3; blue and white porcelain bowl inv.no. 18,17 PHOTOS (C) A. FUSARO

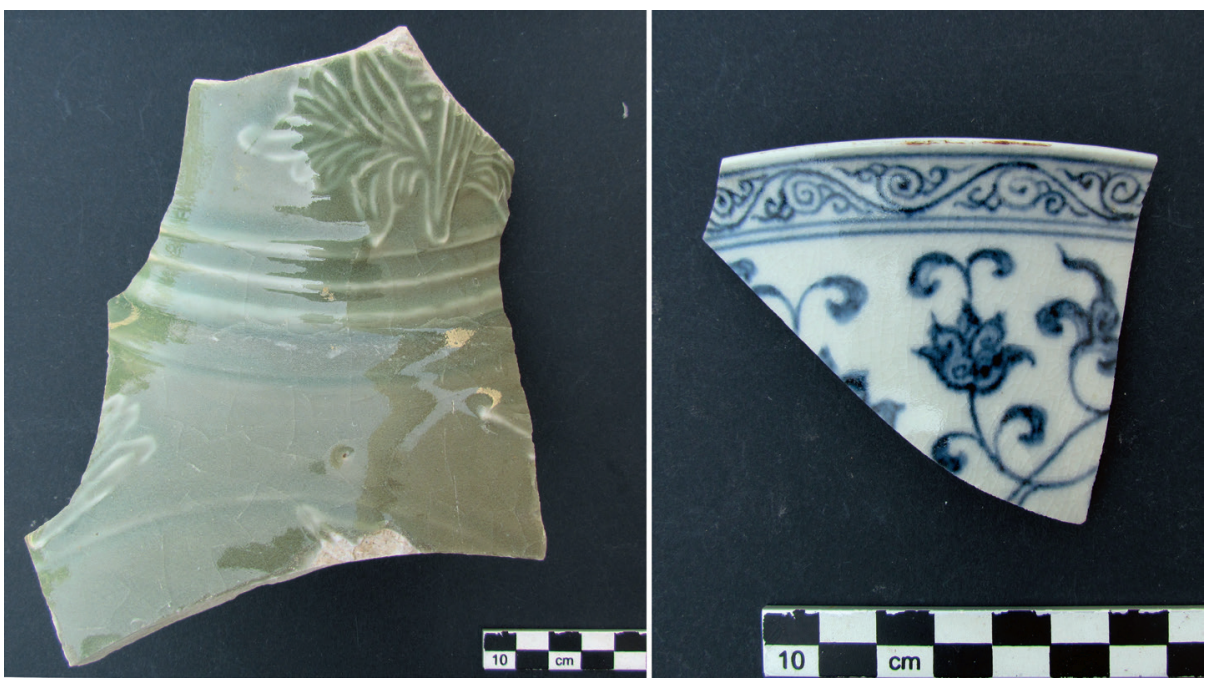

how trade patterns and the role of Zafār changed in different periods, and for which political and economic reasons. The pottery study also gives insights into the wealth of the city and, more specifically, that of its ruling class. In general, the imported items are more abundant in the earlier layers (corresponding to the fourteenth-fifteenth centuries); nonetheless, they are also present in the latest layers, even if in lesser amounts. High-quality and expensive items came from far-away regions, such as Egypt, Iran, and China, but local citizens also liked and demanded medium-quality products, such as Yemeni goods. Indian, Chinese, and Far Eastern ceramics are the most abundant imports. The first represent $4.44 \%$ of the whole corpus, the latter an overall percentage of $2.56 \% .^{14}$

Three different phases have been identified: one related to the fourteenth-fifteenth centuries, the second to the sixteenth century, the last to the seventeenth-eighteenth centuries (Fusaro, 2019: fig. 9).

\subsection{The Fourteenth-Fifteenth Centuries}

During the fourteenth and fifteenth centuries there was a period of intense trade, both short- and long-distance; a good quantity of Yemeni items arrived, as well as Iranian and Egyptian ceramic artefacts, and the bulk of the Chinese imports. In this period the imports represent about $13 \%$ of the assemblages. The variety of imports found and the high quality of many of them may be connected to one of the most flourishing phases of al-Balīd, coinciding with the Rasūlid period. The ruling class of the city demanded and was able to purchase luxury and expensive items, at least from the fourteenth century onward.

About $6 \circ \%$ of the imports from China in circulation at al-Balid during this period consists of celadon dishes, large bowls, and big jars, followed by blue and white porcelain bowls and cups, in total about 19\% (Fig. 9). Many stoneware vessels have also been found, some from South-East Asia. According to the preliminary analysis of Chinese ceramics, the port of al-Balīd was engaged in long-distance trading activity during two main phases: the first one corresponding to the end of the thirteenth and the beginning of the sixteenth centuries, the second one from the eighteenth century onward (Visconti in Pavan et al., 2018: 228; Pavan and Visconti, 2020: 247, fig. 3).

Until the fifteenth century, several fine unglazed high-quality water vessels arrived at the site, most probably from the Iranian regions (Priestman, 2005: 201-202). They are wheel-thrown handled jugs and a few pilgrim flasks made of buff, light grey or white cream fabrics, and usually bear very fine incised and pierced decorations (Fig. 10). 


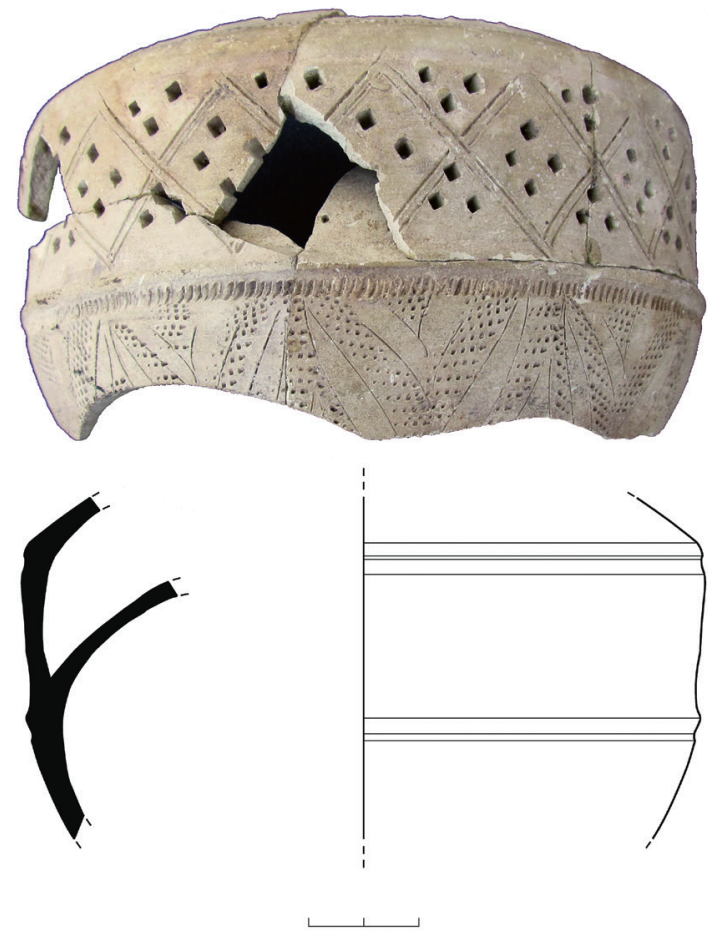

FIGURE 10

Unglazed flask inv.no. 22,447 from the Iranian regions found at the Husn DRAWING AND PHOTO (c) A. FUSARO

Some specimens characterized by a transparent green-turquoise glaze could also have been imported from the Iranian regions (Hansman, 1985: 52; Kennet, 2004: 56), some have been more specifically identified as belonging to the so-called Persian blue speckled ware (Kennet, 2004: 53-54; Hansman, 1985: 52, fig. 12.a, d, f, g, h). The production does not seem of high quality, as the glaze always appears full of air bubbles and impurities, altering its transparency. Most of the specimens are conical bowls with a straight everted rim and ring base (Fig. 11); a few small jars have been also found. They are widespread in almost all the layers, except the uppermost ones, suggesting circulation at least from the fourteenth to the sixteenth centuries onward.

Especially from room A2 of the Husn, a group of vessels identified as imports from Egypt or Syria has been recovered (Fig. 12). They are all made of stonepaste, which is coarser and not as purified as the body of the Iranian imports (see below); the group comprises medium and small bowls decorated with underglaze blue painted motifs, most of them vegetal and floral, which clearly imitate the then contemporary Chinese blue and white porcelain. They have been attributed to the fourteenth-fifteenth centuries (David-Weill, 196o; Peterson, 1980: 66, pl. 4/XIII; Scanlon, 1984: pls 10-11; Jenkins, 1984; Tonghini, 1998: fritware 3, 51-55, fig. 74/g; Watson, 2004: cat.no. S.4, 422-423; Vezzoli, 2011: 132, 136-137, pl. 12). ${ }^{15}$

To date, a unique vessel has been identified as a possible East African product (inv.no. 125,5, Fig. 13). It has been found in the filling of the eastern gate dated to approximately the fifteenth century. It is the high neck of a large jar, characterized by a black/ brown fabric and a burnished surface. It shows similarities to African vessels, especially those from Kilwa (Chittick, 1974: 329, type 33, fig. 136 (b); Rougeulle, 2015: fig. 179.8).

The pottery alone could suggest that the link with Eastern Africa was of no importance for al-Balīd, ${ }^{16}$ however, on the contrary, historical sources (Staples, 2017: 101), as well as other materials collected at the site confirm more intense relations. Coins from the Sultanate of Kilwa dated to the fifteenth century were, for example, collected at al-Balid (Annucci in Pavan et al., 2018: 232). Moreover, the presence at several African sites of almost the same ceramic imports found at al-Balìd (see for example the recent 
FIGURE 11

Monochrome turquoise bowl inv.no. 18,22 from the Iranian regions found at the Husn DRAWING AND PHOTO

(C) A. FUSARO

FIGURE 12

Underglaze painted stonepaste bowl inv.no. 22,245 possibly from Syria found at the Husn DRAWING AND PHOTO

(C) A. FUSARO
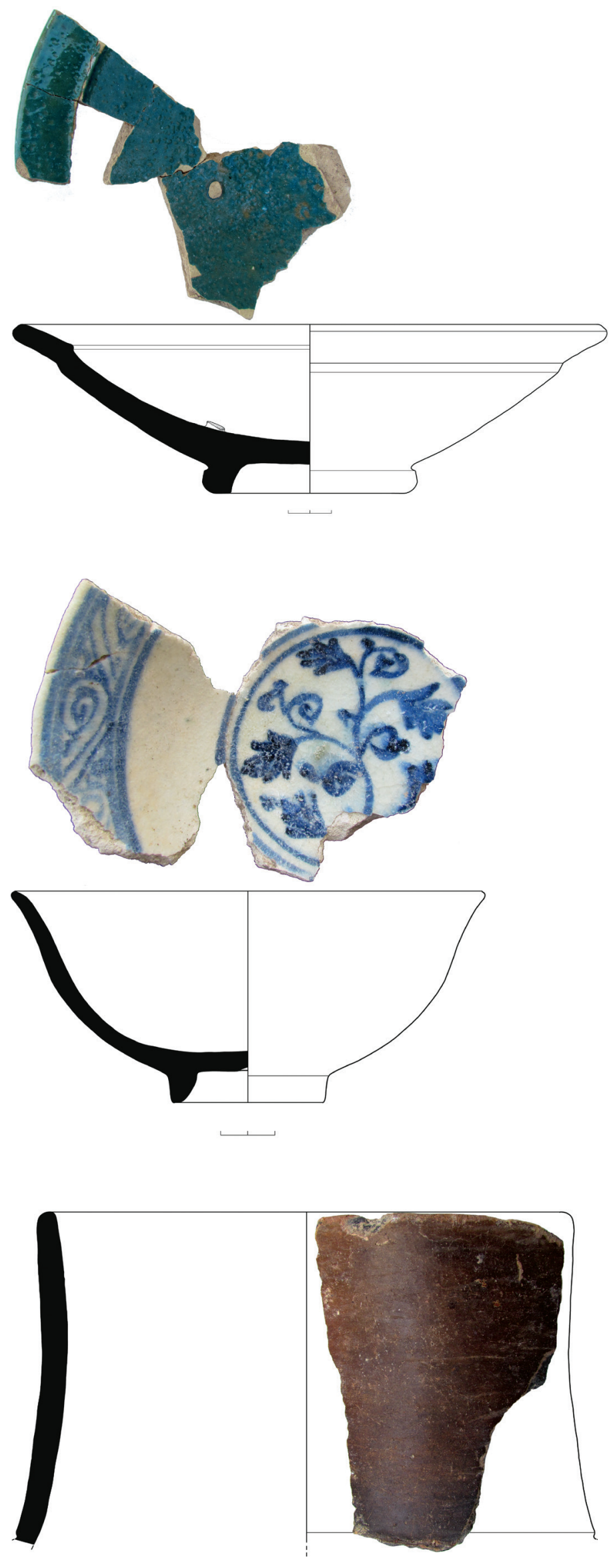

FIGURE 13

Unglazed jar inv.no. 125,5 probably from Africa found at the Husn DRAWING AND PHOTO

(C) A. FUSARO 
research-work in the ports of Somaliland, González-Ruibal et al., 2017) confirmed that al-Balìd and the East African centres were in contact with each other and located along the same commercial routes. Therefore, it is possible that African items other than ceramics were traded between Dhofar and East Africa, thus confirming that different products were in demand, corresponding to the regions with which al-Balīd was in contact.

\subsection{The Sixteenth Century}

During the sixteenth century, there was a drop in imports, which then amount to less than $9 \%$ of the assemblages. This may be caused by the arrival and the assaults of the Portuguese and the Ottomans in the Gulf and the Indian Ocean, and the resulting political and economic decisions of the Kathīin rulers, especially the ban on the trade in horses, frankincense and fish-oil around the mid-sixteenth century (Zarins and Newton, 2017a: 81).

\subsection{The Seventeenth-Eighteenth Centuries}

Zafär enjoyed an economic recovery and a new impulse in the trade with and through Dhofar in the seventeenth-eighteenth centuries: Yemeni ceramics, specimens of Bahla ware from Northern Oman, products from the Gulf area, a good quantity of items from Safavid Iran, a few objects probably from Egypt, but also Chinese vessels reached al-Balìd. In this period the imports reach an average of $13 \%$ of the assemblages. Especially the finding of high-quality products at the Husn, such as blue and white porcelains and Iranian stonepaste artefacts, seems to point to the presence at al-Balìd of a rather affluent social class still demanding luxury ceramics.

At al-Balid high-quality imports from Iran were traded at least from the fourteenth century onward; they are among the most beautiful ceramic objects circulating at the site. These bowls and dishes are made of a compact stonepaste, usually bearing a blue painted decoration under a transparent colourless/whitish glaze (Fig. 14 ${ }^{17}$ ); they probably date from the Timurid to the Safavid periods. The decorative patterns are always fine and complex, consisting of floral, vegetal and zoomorphic motifs that usually imitate contemporary Chinese porcelain vessels. Dated to the Safavid period (sixteenth-early eighteenth centuries) there are also several small fragments of underglaze blue and black painted ware, mainly consisting of bowls and cups (Fig. $\left.14^{18}\right)$. A unique piece, found in the uppermost layer of the south-central area, is a ring base of coarse buff stonepaste (Fig. 15); its ribbed decoration on the outer surface, and the sea-green glaze covering it, clearly testifies to an imitation of Chinese celadon; similar vessels from Iran have been dated to the seventeenth century (Watson, 2004: 465, cat.no. U.17, see also Kennet, 2004: 55-57).

Buff earthenware, large shallow bowls and dishes from Iran have been collected from layers dated to the sixteenth-eighteenth centuries (found in the central-eastern area and room A33; Fig. 16). Their form and colour combinations of glaze and paint suggest that they were imitations of more expensive contemporary stonepaste items circulating in Iran during the Safavid period.

Two unique specimens, found exclusively in the upper layers of the south-central area (seventeenth-eighteenth centuries), belong to a ware whose origin and features are still largely unknown: the so-called Red-Yellow ware. They are characterized by a fine buff clay body, covered with a red/brownish slip which is incised and carved to create a geometric pattern, the glaze is transparent mustard-yellow (Fig. 17). Identical items were found in Ra's al-Khaimah and al-'Ain (Kennet, 2004: 56; Power, 2015: fig. 7). According to the texture and the colour of its fabric, this ware could also originate from Iranian or Iraqi regions. 
FIGURE 14

Iranian underglaze painted stonepaste items found at the Husn: ring base of a dish inv.no. 48,10; bowl inv.no. 1,534 PHOTOS (C) A. FUSARO
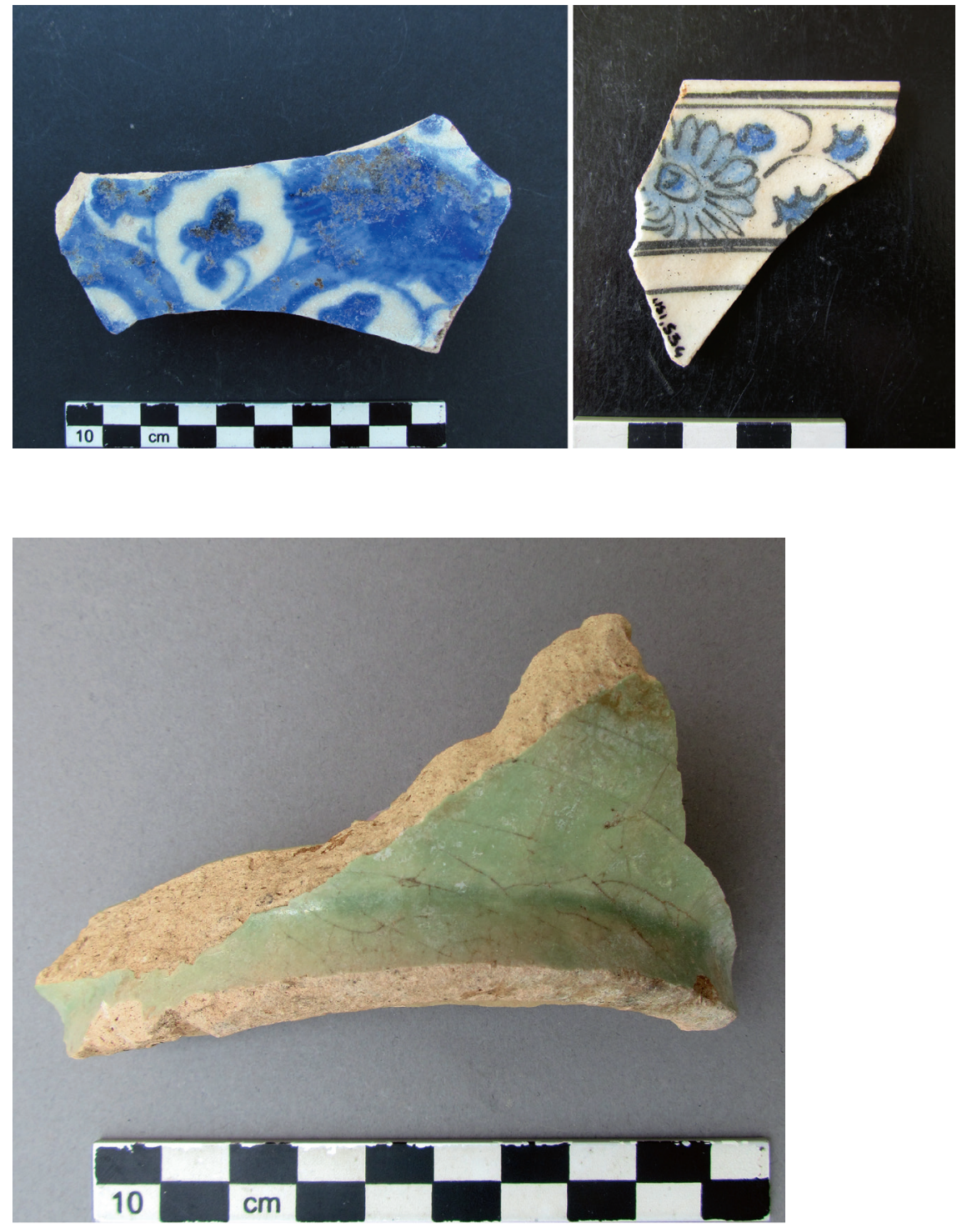

FIGURE 15

Ring base inv.no. 101,1 of Iranian sea-green glazed stonepaste bowl found at the Husn PHOTO (C) A. FUSARO

FIGURE 16

Iranian earthenware underglaze painted large dish inv.no. 83,15 found at the Husn PHOTO (C) A. FUSARO

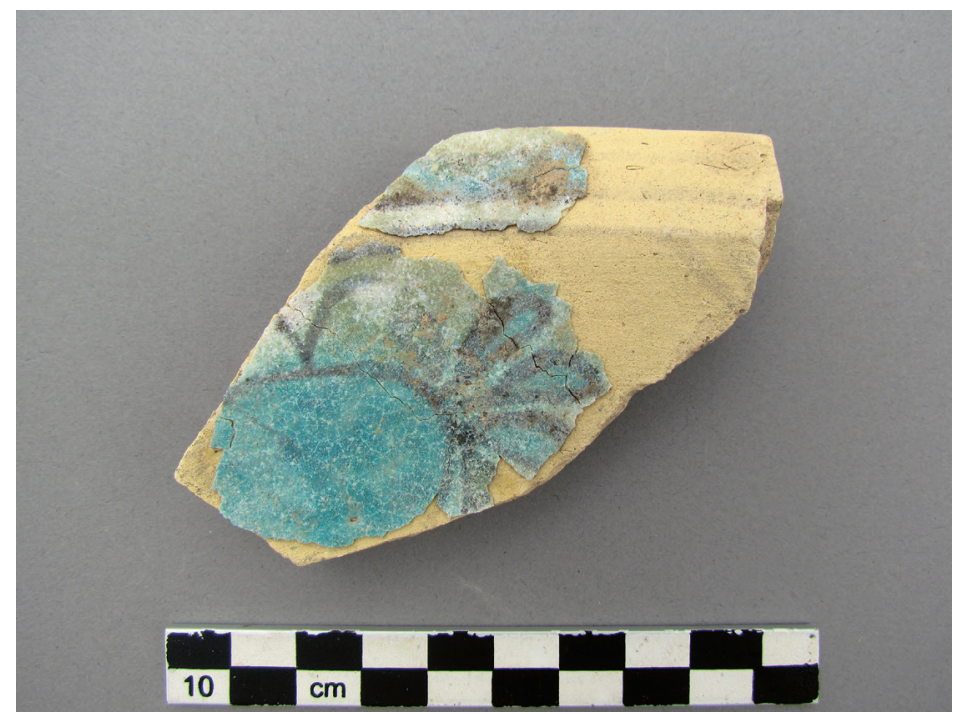



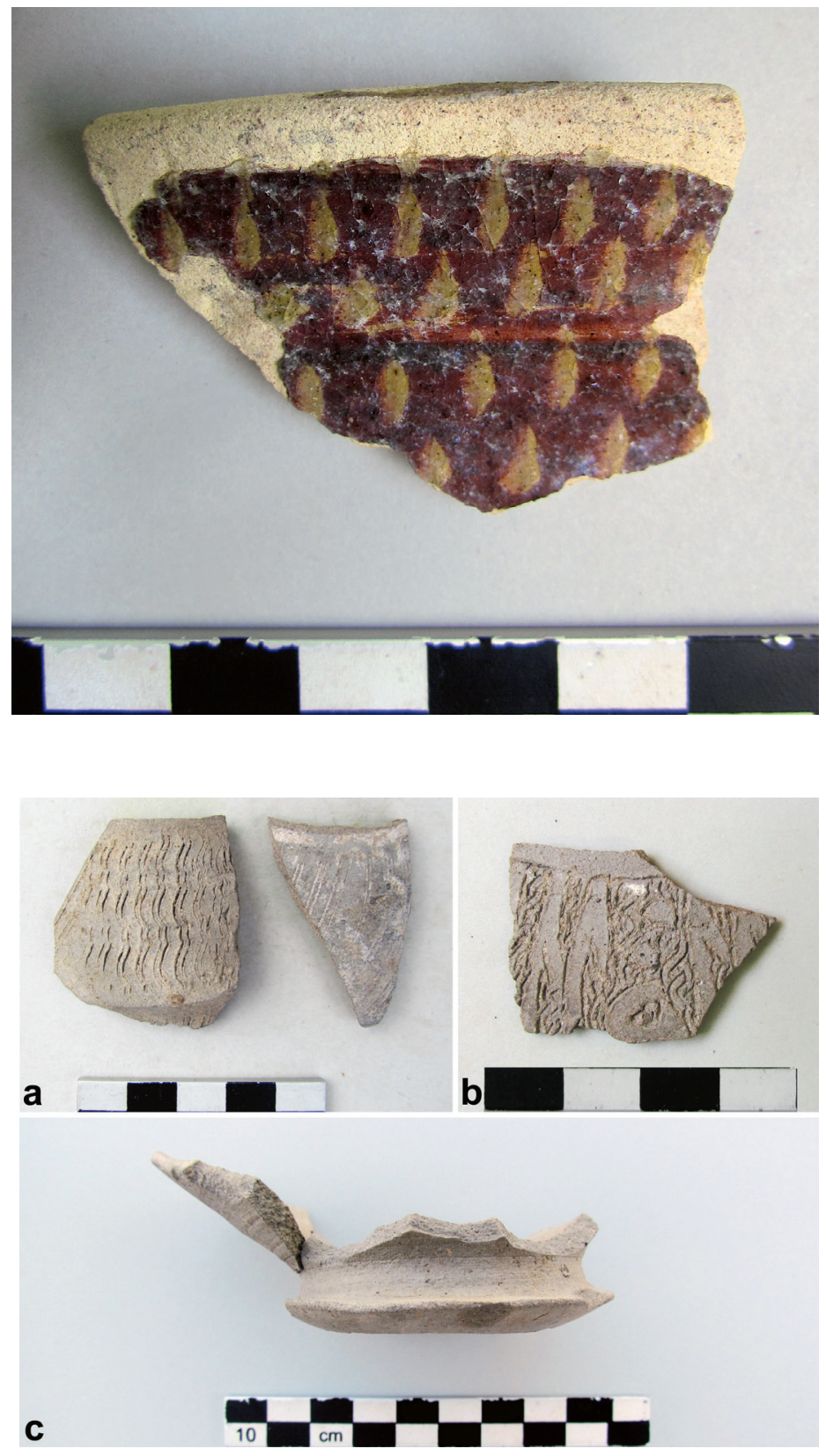

Especially the circulation of several Persian products at the site in the seventeentheighteenth centuries in particular, was probably an effect of the Iranian political and economic intervention in the Indian Ocean: since the beginning of the seventeenth century, they challenged the Portuguese, i.e. by making treaties with the Ottomans and the English (Floor, 2017:128).

Far Eastern imports, already mentioned above, even if less present in the uppermost layers, are still quite well-represented within the assemblages. They mainly consist of polychromous porcelain items, such as blue and white bowls, specimens with red enamel paint, and Batavia cups, while the number of celadons sharply decreases.

Fragments of unglazed thin vessels, mainly jugs with high necks and ring bases, made of a fine grey fabric, have been identified as Egyptian imports (Fig. 18; for similar items, see Smith et al., 2012: 180-181). They always bear an incised decoration, which sometimes consists of epigraphic bands in Arabic (Fig. 18.b). As suggested by the analysis of the archaeological contexts, this production is widespread exclusively in the latest
FIGURE 17

Iranian earthenware underglaze slipped bowl from SU 101 found at the Husn

PHOTO (C) A. FUSARO
FIGURE 18

Fragments of unglazed grey jugs probably from Egypt found at the Husn: a. inv.nos. 1,251 and 1,411; b. sherd with epigraphic band from room A2; c. ring base inv.no. 100,5 PHOTOS (C) A. FUSARO 


\section{FIGURE 19}

Specimens of Bahla ware found at the Husn: a. small dish inv.no. 10o,19; b. large shallow bowl inv. no. 100,18; c. conical bowl inv. no. 100,17; d. bowl with ribbed surfaces inv.no. 12,16; e: different specimens from the uppermost layer of the central-eastern area DRAWINGS AND PHOTO (C) A. FUSARO
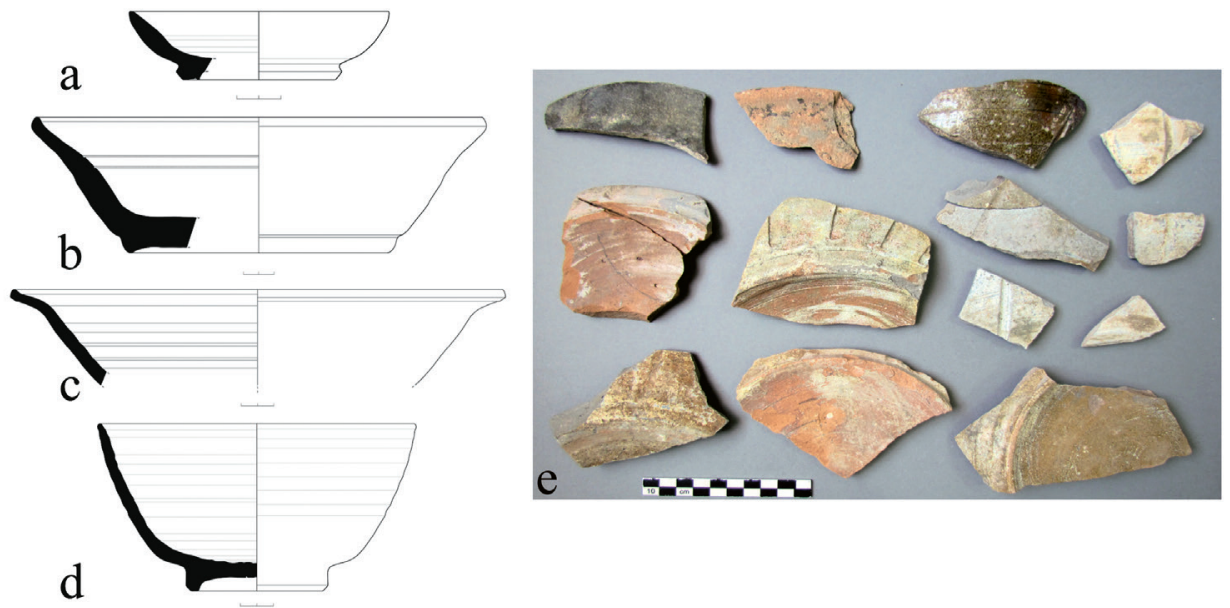

phase of the occupation of al-Balìd, during the seventeenth-eighteenth centuries, thus proving that contacts with the westernmost lands extended to the very late period.

Within the pottery corpus from the Husn, there are some specimens that belong to Bahla/Khunj ware (Fig. 19); Bahlā or other centres of Northern Oman, and Khunj, South-Western Iran, have been suggested as production centres (Hansman, 1985:52-53; Kennet, 2004: 54-55; Priestman, 2008: 278; Power, 2015:10-11). The vessels found at al-Balīd are characterized by a transparent olive green-brown glaze, frequently speckled and of low-quality, and usually without slip (Fig. 19.e); the surfaces often appear ribbed (Fig. 19.d). The morphological typology comprises large conical bowls and dishes, there are also small carinated bowls and some jars. This ware is mostly found in the upper layers, thus suggesting a wide circulation during the seventeenth-eighteenth centuries. However, a tiny amount of sherds has been found in one of the lower layers, indicating that it appeared during the fifteenth-sixteenth centuries. ${ }^{19}$

All considered, despite the paucity of architectural evidence pertaining to this last occupational phase, the pottery analysis testifies that al-Balid was a very active port until the eighteenth century and possibly later. The population living in the city still demanded, and was able to afford high-quality imports. Along with them, other medium-quality objects were still imported from closer regions, such as Yemen (see below) and Northern Oman.

In the same period, a significant refinement and an increase in quality of local ceramic manufacturing have been detected.

Both the remarkable variety of the imports and the revival of the Dhofari pottery tradition during this phase could be explained with the rise of the Ya'rubid (1624-1749) and the Âl Bū Sa'īd (1749-) dynasties, under which there was an intensification of cultural unity in the Western Indian Ocean, and a substantial trade expansion, especially from the seventeenth century onward. Both dynasties are responsible for the creation of the modern nation of Oman (Nicolini, 2017: 141, 143, 155), the Āl Bū Sa'îd included Dhofar in this nation (Peterson, 2004: 257; Nicolini, 2017: 147). The latter could also explain the abundance of the Bahla ware, circulating at al-Balīd in a period when new, stronger relations were started between Northern and Southern Oman.

Finally, the temporary control of the Ya'rubids over Julfār/Ra's al-Khaimah between the seventeenth and the eighteenth centuries (Power, 2017: 233) could also explain the finding in the latest occupational phase of the Husn of two hand-made painted jars (Fig. 20), probably from Julfār (Hansman, 1985: 6o-64, figs. 14, 17; Kennet, 2004: 70-1; Mitsuishi and Kennet, 2013: 3, fig. 4 style 5; Saunders, 2013: 300, 'Julf4'). ${ }^{20}$ 


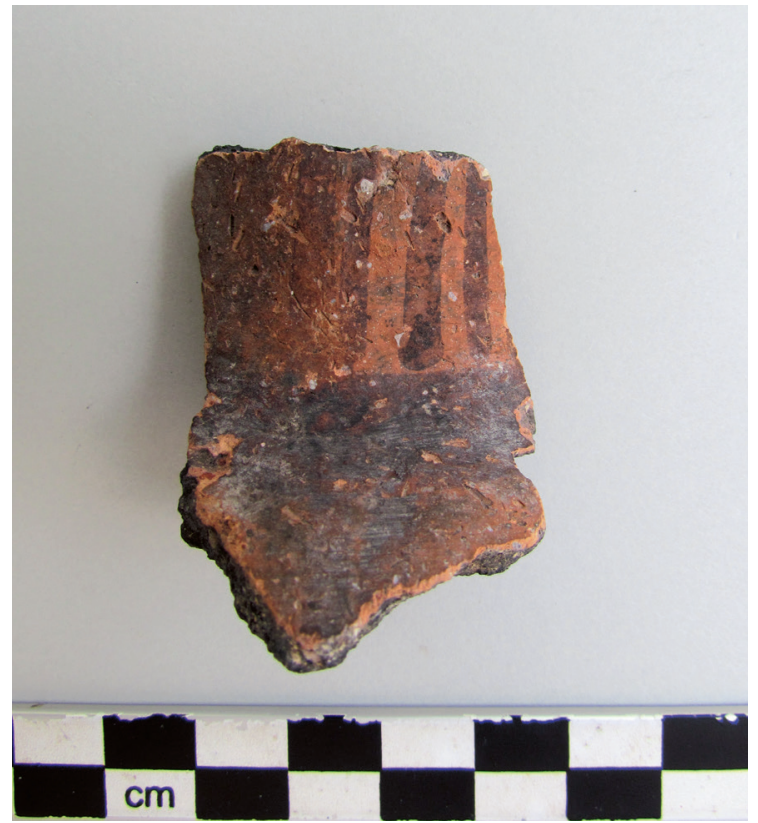

\subsection{The Strong Relation with Yemen}

The continuous circulation at al-Balìd of a large number of Yemeni ceramic imports, both glazed and unglazed, clearly suggests that the city maintained strong, durable relations with this neighbouring country, at least during the whole time span considered so far (fourteenth-eighteenth centuries). From a historical point of view, the abundance of Yemeni products could be explained with the presence of the Habūdī and Rasūlid dynasties of Yemeni origin. It could also possibly suggest the presence of Yemeni people at the site. Indeed, at the time of the Habūdī dynasty, it seems that a good number of Yemenis, probably from Hadramawt, moved to al-Balīd in order to populate the newly reconstructed city of al-Manșurā (Smith, 1985: 85; Smith, 1988: 28; Smith, 2005: 413). Moreover, at the time of the Rasūlid conquest, Yemeni merchants started their trade in the region.

At least five glazed wares have been recognized as Yemeni productions. The first one is the so-called Yemeni Yellow ware (Kennet, 2004: 53), also known as Mustard ware (Whitcomb and Johnson, 1982: 137-138, pl. 37; Hardy-Guilbert, 2005; Pradines, 2010: 222-224 \& 259-261) or Black-on-Yellow (Horton, 1996: 291). It comprises mainly conical bowls painted in dark brown/black under a transparent yellow glaze (Fig. 21.a). The glaze is almost always badly preserved. Within the stratigraphy of the Husn, specimens of Yemeni Yellow ware have been found almost exclusively in the earlier layers, thus suggesting that they were spread at least during the fourteenth-fifteenth centuries.

Also coming from Yemen, as suggested by similar fabric and glaze features, there are two unique bowls attributed to the fourteenth-fifteenth centuries, whose decoration is obtained by juxtaposing large vertical bands of turquoise and yellow glazes (Fig. 21.c) (Whitcomb and Johnson, 1982: 138, 148, Yellow-Blue Ware, pl.138/v, x, z, aa).

The fabric analysis also suggests that many monochrome turquoise bowls and underglaze blue, black and/or turquoise painted vessels are from the same regions of the aforementioned wares (Fig. 21.b)..21

Very few fragments, exclusively found in layers attributed to a phase later than the fifteenth century, have been associated with another type of Yemeni pottery production, the so-called Tihamah ware. They are open vessels - one is a hemispherical bowl with
FIGURE 20

Fragment of unglazed painted jar inv.no. 100,1 probably from Julfār found at the Husn PHOTO (C) A. FUSARO 
FIGURE 21

Imported glazed items from Yemen found at the Husn: a. Yemeni Yellow ware (inv.no. 73LW,62); b. underglaze painted ware (inv.no. 1,536); c. bichrome ware (inv.no. 105,8); d. Tihama ware (inv.no. 1,346); e-f. Haysi cups (inv.nos. 83,18; 100,3); g. Haysi shisha pipe from the uppermost layer of the central-eastern area PHotos (C) A. FUSARO
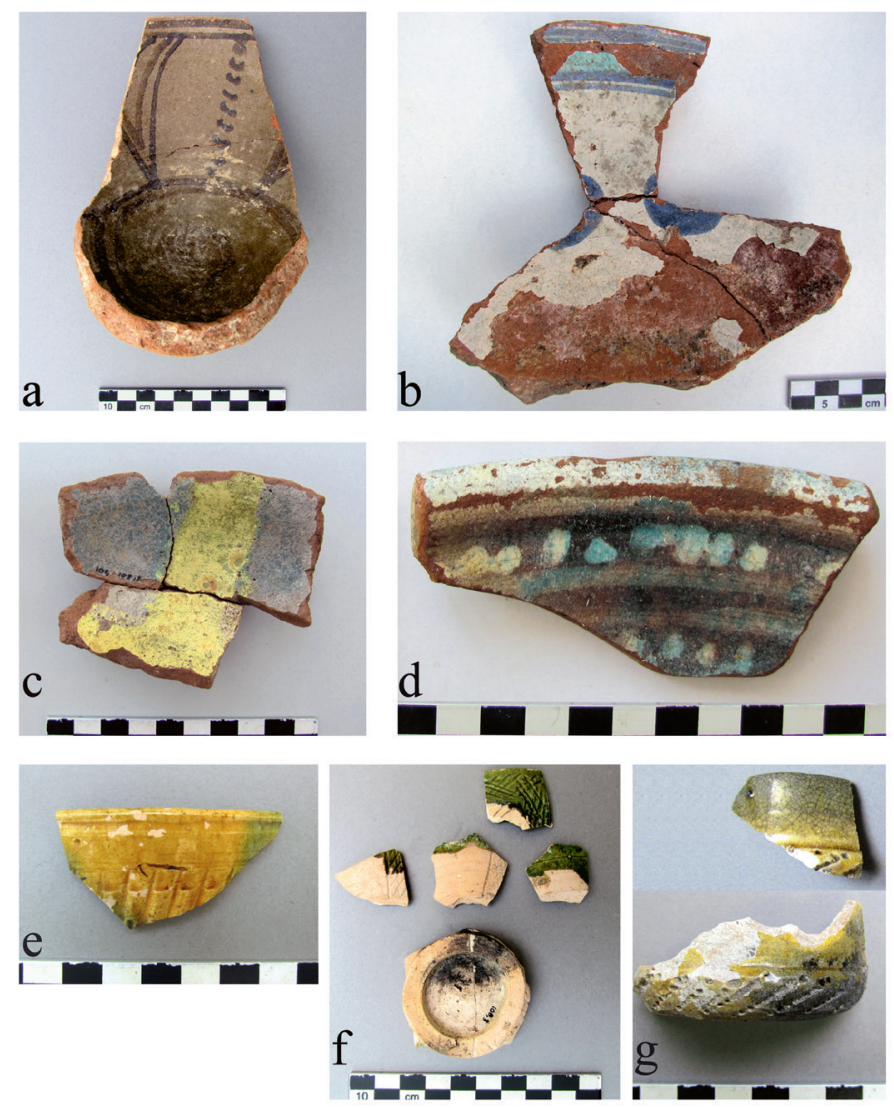

a thickened rounded rim (Fig. 21.d) - characterized by a white slip-painted decoration directly on the ceramic body, covered by a transparent turquoise glaze. The Tihamah ware is usually dated to the thirteenth and the sixteenth centuries (Keall, 1983: 383; Hardy-Guilbert and Rougeulle, 1995: 33-35).

The finding in the later occupational phases of the Husn of several coffee cups and a fragmentary shisha pipe ${ }^{22}$ (Figure 21.e-g), typical of Hays (Keall, 1983: 383, fig. 4/14; Keall, 1991: 83-84, figs. 10-11; Keall, 1992: 30-32) confirms that in the seventeenth century relations with Yemen were still very intense (Nicolini, 2017: 144-145), also with respect to the coffee trade.

Along with the glazed vessels, unglazed items can be recognized as Yemeni products. The best example is a small pot characterized by white slip and incised geometric decoration (inv.no. 73LW,61; Fig. 22.a), for which a close parallel has been found among the vessels from the Zabìd area (Ciuk and Keall, 1996: pl. 95/41). There are also jars and jugs possibly originating from the same area (Keall, 1983: 383, fig. 5; Ciuk and Keall, 1996: pl. 95/12, 14, 17), with white slipped or light-coloured surfaces and incised decoration (Figs. 22.b-c).

A striking resemblance between a fragment of a jar/jug imported from Yemen (inv.no. 105,7) and a fragment from a vessel locally manufactured (inv.no. 106,7), with a very similar decoration must be pointed out (Fig. 22.d). ${ }^{23}$ Other similarities have been detected between the unglazed items produced at al-Balīd - especially large and medium bowls and pots of the grit temper ware - and products from Yadhghat, in Hadramawt. ${ }^{24}$ This is evidence once more of the intense relations of al-Balīd with Yemen, even in the shape of imitations or common fashions. Indeed, Dhofar was always culturally much closer to Yemeni regions, especially Hadramawt, than to the rest of Oman (Peterson, 2004: 254-255). Moreover, Ibn Baț̣ūṭa considered Zafār as the last (westernmost) city of 

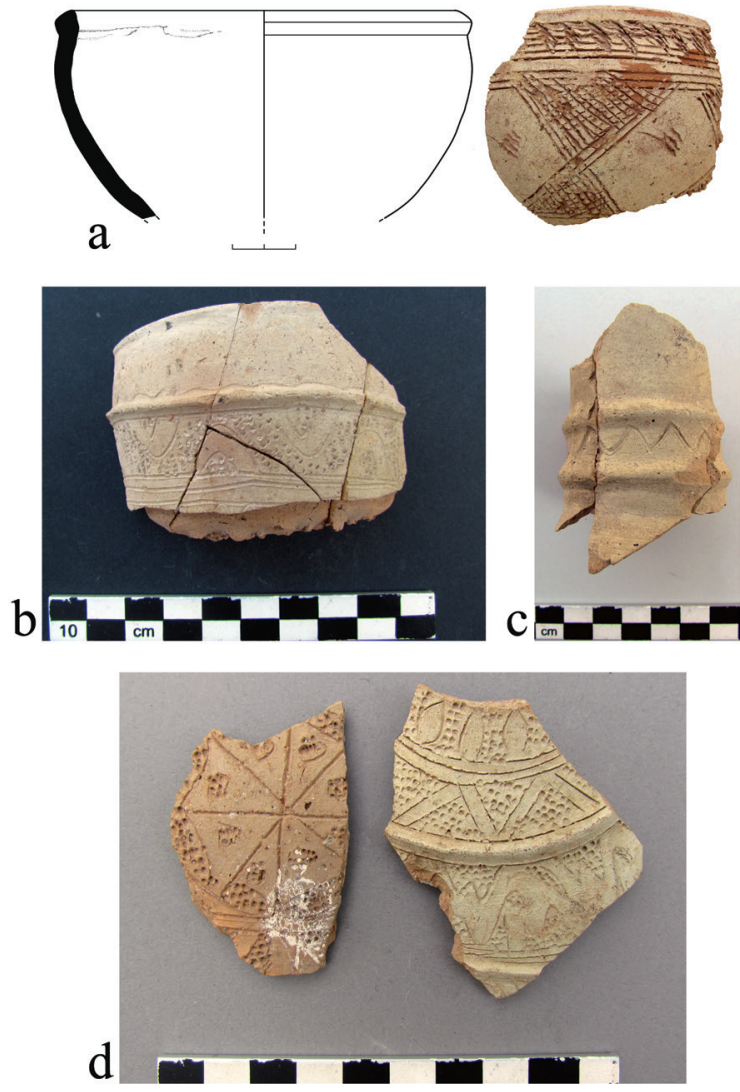

Yemen, while he probably referred to the northern part of the present-day nation when he spoke of Oman (Defremery and Sanguinetti, 1969: 196; for other historical sources, see also Tkatsch, 1934: 1255).

\subsection{Peculiar Imported Containers}

Among the imported items, there are also a few storage jars that preserve a coloured contents inside (Figs. 23-25).

The first is a large jar whose ceramic body contains shell temper, its form recalls Indian products, and it has a red contents (inv.no. 18,96, Fig. 23); it has been dated to approximately the fifteenth century based on its assemblage found in room A2. It could be from the Indian subcontinent, or it could be a local vessel imitating Indian shapes and containing local pigment, such as madder, widely exported to the Indian coast (Newton and Zarins, 2017:102). The second is a flat base of a wheel-thrown jar with a red residue (inv.no. 101,3, Fig. 24); it arrived from the Gulf area, possibly Iran, as suggested by the fabric of the vessel, ${ }^{25}$ during the seventeenth-eighteenth centuries, based on its assemblage from the south-central area.

Two more fragments recovered at the Husn preserve a red powder inside; the archaeometric analysis carried out at the University of Zaragoza (Spain $)^{26}$ allowed us to identify the pigment as cinnabar. This material was also found inside several shells collected at the Husn. Cinnabar could come from China, one of the most important sources of this pigment in the world.

A fragment of a large jar with a dark blue contents was also found, possibly indigo (inv.no. 100,13, Fig. 25). It has been attributed to the seventeenth-eighteenth centuries, in accordance with its assemblage found in the central-eastern area. It could have been imported from Yemen, Northern Oman, or even Dhofar (Newton and Zarins, 2017: 101);
IGURE 22

mported unglazed items from emen found at the Husn: a. white lipped pot inv.no. 73LW,61;

-c. jugs inv.nos. 22,155 and 18,42; . comparison between a local roduct (on the left, inv.no. 106,7) nd a Yemeni import (on the right, iv.no. 105,7)

IRAWING AND PHOTOS

:) A. FUSARO

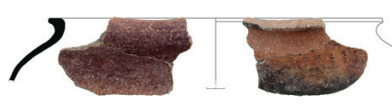

FIGURE 23

Imported unglazed jar inv.no.

18,96 with red content recovered

at the Husn

PHOTO (C) A. FUSARO

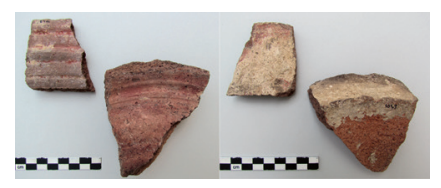

FIGURE 24

Imported unglazed jar inv.no. 101,3 with red content recovered at the Husn

PHOTO (C) A. FUSARO

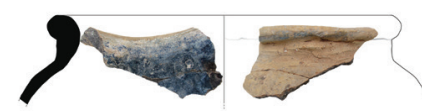

FIGURE 25 Imported unglazed jar inv.no. 100,13 with blue content recovered at the Husn PHOTO (C) A. FUSARO 


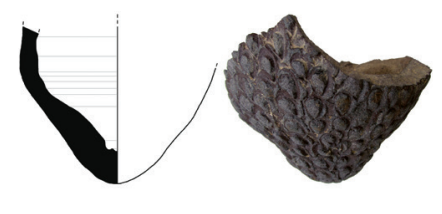

FIGURE 26

Base of sphero-conical vessel found at the Husn, inv.no. 73,4 DRAWING AND PHOTO (C) A. FUSARO in the latter case, it could belong to a small group of unglazed hand-made large vessels possibly made in the region. ${ }^{27}$

Archaeometric tests are planned to confirm the provenance of these jars. As they are not high-quality vessels, to be sold for their intrinsic or aesthetic value, they must have been imported for the load transported inside them, thus confirming a circulation of specific goods, such as colouring matters.

At the Husn a unique incomplete sphero-conical vessel has been found in a layer of the rooms $\mathrm{A}_{52}{ }^{-} \mathrm{A} 57$ dated to the fourteenth-fifteenth centuries (Fig. 26). It is made of a highly overfired, dense and compact grey-violet fabric. The surface is grey, but the outer surface appears darker. This overfired earthenware container has a wheel-thrown spherical body with a pointed base and bears a dense stamped relief decoration, consisting of inverted drops. It belongs to a category of objects found in many Islamic contexts throughout Asia, but it is unusual in the regions of the Indian Ocean. ${ }^{28}$ The item collected from the excavations at the Husn is until now the only one of this category found at the site of al-Balīd. It shows a strong resemblance to items from Egypt from the Mamluk period (i.e. thirteenth-fifteenth centuries), especially those found at Cairo/ Fustat (Monchamp, 2016: 200-202, fig. 3; see also Whitcomb and Johnson, 1982: 119, pl. 49.i; François, 1999: fig.14, pl. 7, 13, 140-142; Stern, 2012: 94). Due to its uniqueness, the vessel could have possibly arrived at al-Balīd with a merchant or a traveller coming from Egypt who brought it as an item for personal use or a gift, rather than a good to be sold. ${ }^{29}$

\section{Cultures and Communities of the City}

Finally, the ongoing examination of the pottery from the Husn provides us with information on the different cultures and communities of al-Balīd.

\subsection{The Indian Community}

From historical sources, we may conclude that at least throughout the Islamic period, Zafär had strong relations with the Indian subcontinent. Indeed, it was one of the most important and convenient stops on the one month journey to these lands, (Guest, 1935: 406; Defremery and Sanguinetti, 1969: 196; Varisco, 1993: 20). Moreover, the city re-exported Indian products to the westernmost lands (Newton and Zarins, 2014: 269), and it also imported rice, the principal food source for local people, and cotton, for local clothing production (Guest, 1935: 406; Defremery and Sanguinetti, 1969: 197-199). This strong link with the Indian subcontinent could have also led Indian people, probably merchants, to settle at the site.

The presence of Indian people at al-Balīd, already suggested by Newton and Zarins, ${ }^{30}$ is confirmed by the impressive amount of Indian vessels recovered at the Husn. They are among the most abundant imports within the pottery corpus, representing $31.37 \%$ of them, and they have been found in all the layers examined. The vessels mainly consist of unglazed coarse red and grey items, comprising pots of many different sizes, and jars in a lesser quantity, shaped by using moulds or the paddle and anvil technique (Fig. 27). The variety of forms and fabrics is remarkable. Only very few bowls and dishes are made of very fine body and are wheel-thrown, thus representing higher-quality unglazed vessels.

Most of the Indian imports are medium- or low-quality products, and many are cooking vessels, as suggested by the soot marks; they do not show any aesthetic value, they are rather simple functional vessels. They seem to have been exported to al-Balīd by Indian people to sustain their specific dietary habits, but they were probably also used as containers for the transportation of items to be sold at the site. Therefore, it can be 


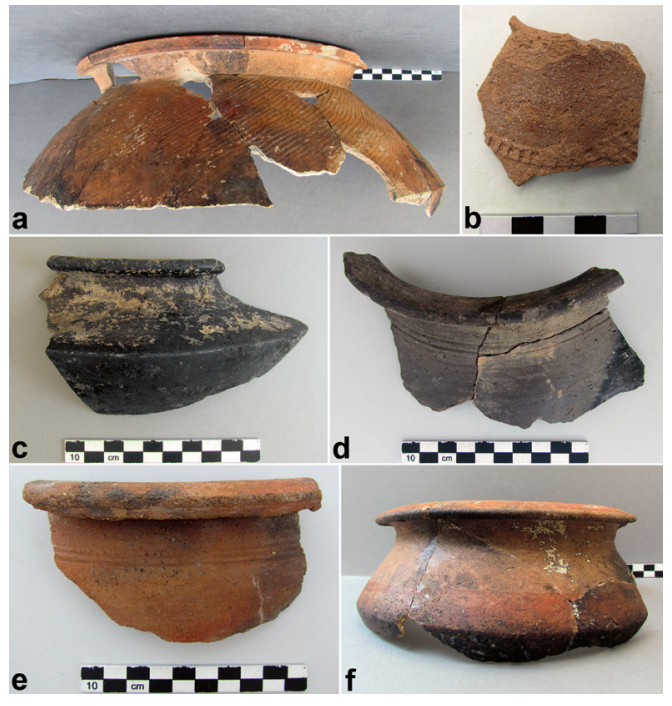

suggested that Indian people migrating to Dhofar brought their traditional vessels for the transportation of goods and foodstuffs; once settled, they probably used them for cooking.

Pots and people came from different regions of the Indian subcontinent that have been identified through a preliminary study of their features and the comparative analysis of coeval ceramic corpora.

Pots with the peculiar paddle impressed decoration on the exterior (Fig. 27.a) could be imported from southern India, as the paddle technique is usually associated with the southern Indian regions, especially the coastal sites (Collinet, 2015:166). In the Medieval Period this ware seems particularly wide-spread in Tamil Nadu, Kerala, Andhra Pradesh, but also in Maharashtra (Selvakumar, 2011: 203). Some of the vessels found at the Husn also show parallel fine horizontal lines on the inner surface: they were probably left by bamboo or other wooden sticks used for finishing and smoothing the surface (Reddy, 2016: 69-70); this technique is still common in the pottery manufacturing of Kerala (Pavan, personal communication). Some of the paddle-impressed vessels that were found could also have come from Sri Lanka, as suggested by the strong resemblance to a typical local fabric of the pottery from Tissamaharama (Schenk, 2014: 105, fig. 8,4) and the ceramic body of a few paddle-impressed carinated vessels from al-Balìd (fabric labeled 'coarse dark red 3'). Other ceramics made of the same ceramic body, such as large pots and small-medium pots coated with red paint/wash (Figs. 27.e-f), and even possibly a small fine grey bowl with a ring base and well-polished silvery surfaces, could have also been imported from Sri Lanka. ${ }^{31}$

Grey/black pots whose bodies show abundant vegetal temper along with a few micaceous inclusions and black or red burnished surfaces (Figs. 27.c- $\mathrm{d}^{32}$ ), could originate from the north-western regions, especially Gujarat ${ }^{33}$ (Tomber et al., 2011; Nanji, 2011: black slipped grey ware, 69-70). A few pots with a splayed rim and from coarse red fabric can be safely compared to similar vessels from sites of the coastal area of Sindh (Pakistan). ${ }^{34}$ Closed vessels with moulded relief decoration and a micaceous coating (Fig. 27.b) probably come from the same region (Kervran, 1996: 43, fig. 8-A.7).

The quantitative analysis of Indian pottery in the stratigraphy of the Husn suggests at least two different periods (Fusaro, 2019: 138-143). First, a considerable quantity of Indian coarse wares was found in layers from the fourteenth-fifteenth centuries (overall average of $6.45 \%$, ranging between 4.6 and $9.8 \%$ in the single assemblages), indicating a sizeable Indian community living in the city.
FIGURE 27

Unglazed imports from the Indian subcontinent collected at the Husn: a. paddle-impressed pot inv. no. 22,131; b. pot with micaceous coating inv.no. 1,728; c. carinated grey pot inv.no. $73 \mathrm{~L}, 19$; d. grey pot inv.no. $73 \mathrm{LW}, 65$; e. large pot inv. no. 10,157 ; f. small red painted carinated pot inv.no. $73 \mathrm{~L}, 27$ PHOTOS (C) A. FUSARO 


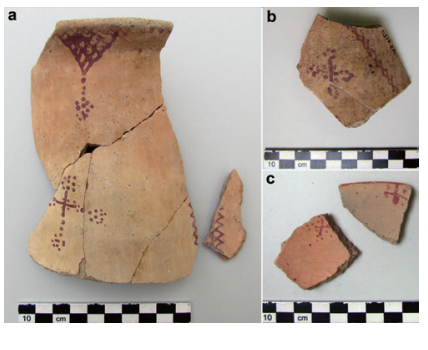

FIGURE 28

Local unglazed items bearing a dotted cross painted in red, recovered at the Husn:

a. jug inv.no. 83,8; b. neck of jug from room A2; c. fragments of two bowls from room A2 PHOTOS (C) A. FUSARO
Second, a remarkable drop in Indian items (overall average of 1.4\%, ranging between 1 and $2.7 \%$ in the single assemblages) seems to prove that the number of Indian people at the site, as well as trade with the Indian subcontinent, strongly decreased. Hypothetically, both aspects could probably be related to the fact that from the the sixteenth century onward, the Indian subcontinent and the trade of its items were widely dominated by European powers, thus contributing to a decrease in direct free relations of Indian merchants and communities with the Arabian peninsula.

\subsection{The Christian Community}

Following the suggestions by Zarins and Newton (Zarins and Newton, 2017b: 94-95, figs. $4 a-4 b)$, but focusing exclusively on al-Balīd, the present research leads to the recognition and a better understanding of the presence of Christians at the Dhofari port city, but also results in the revision of the chronology previously proposed.

This can be deduced from a group of local pottery found in the uppermost layers of the Husn, corresponding to the last occupational phase of the seventeenth-eighteenth centuries. Eight high-necked jars and bowls, belonging to the local grit temper ware and red ware, bear a red painted cross-motif, characterized by dotted edges (Fig. 28). This cross seems to be a simplified version of a trefoiled or trilobed cross; preliminary research has so far revealed interesting shared similarities with at least three cross symbols used by different Christian communities. The motif can be associated with the cross characterised by trilobed edges of the Jesuits order; a similar cross is also commonly used by the Nestorians or Persian Christians. There could also be a link with the cross with floral edges of the Saint Thomas Christian community spread throughout South India. The motif of the flowery cross is particularly widespread on religious buildings and monuments in Kerala, Goa, Tamil Nadu, and Sri Lanka. ${ }^{35}$

In the first case, the presence of this motif in the local pottery of al-Balīd could possibly be explained with the Jesuit missions spreading Christianism all over Asia from the sixteenth century onward, but also by the fact that the Kathīrī rulers, especially Badr Bū Tuwayriq (1516-69), had no particular religious hatred for the Portuguese (Beckingham and Serjeant, 1950: 203; Smith, 2007: 522).

In the second case, the cross motif can be linked to the presence of Nestorianism in Oman and Hadramawt since the fourth century. Written sources and archaeological evidence prove that this religious belief managed to survive after the spread of Islam, at least until the ninth century, but probably longer (Carter, 2013: 326-327; Beckingam and Serjeant, 1950: 197, note 3). Indeed, in the thirteenth century, Ibn al-Mujāwir reported that there were still Christians living in Najrān, also known as al-Ukhhdūd (South-Western Saudi Arabia), and they constituted one-third of the population. Moreover, there is evidence that in Tārim (central Yemen) a church still existed in the sixteenth century (Serjeant, 1959). The presence of Nestorians on the island of Socotra until the fifteenth century is confirmed by several sources (Zarins and Newton, 2017b: 94-95). We cannot exclude that Christians from this island, but also possibly from other westernmost sites, such as those mentioned above, visited or settled in al-Balīd. This movement of human groups could also be explained by the continuous migratory flows that occurred in the lands ruled by the $\bar{A} l \mathrm{Bu}$ Saīd dynasty in the seventeenth-eighteenth centuries (Nicolini, 2017: 146).

The cross motif on the local pottery of al-Balid could also be explained with the arrival at the site of a Christian community from the Indian subcontinent. In fact, from the late sixteenth century onward, the encounters of the Indian Saint Thomas Christians and the Portuguese Jesuits, who began their missionary activities in India, led to a religious dispute and a tragic schism; this could have possibly induced some Indian Christians to migrate to other lands (Moffett, 2005: 12-16; Malekandathil, 2017). 
The study of the pottery from al-Balīd provides further information on the ancient port city Zafār, its history, economic development, social texture, and cultural life. Prosperity and times of crisis are strictly related to the history of the Indian Ocean trade. Its strategic position along the Indian Ocean, and the strong interdependence of Zafār and neighbouring regions gave the port city an important socio-economic role, connecting communities and countries, and allowing exchanges between land and sea.

The study proves that al-Balīd/Zafār always maintained relationships with the communities living inland, mainly in the form of interchanges. Moreover, the large amount of imported pottery recovered during the excavations, also comprising luxury and highquality vessels, proves that it was an important trading centre, intensively involved in the Indian Ocean long-distance commerce networks since the thirteenth century until the late eighteenth, and even possibly the beginning of the nineteenth centuries. Numerous unglazed and hand-made wares locally produced, which are much simpler, but lively and varied, were found in identical archaeological contexts. This striking diversity in ceramics circulating at al-Balīd, along with the richness and the remarkable variation of the materials recovered, testifies to the coexistence of different traditions, related to a variety in fashion and technology, and also to various social classes. The pottery also reflects the coexistence of several communities (i.e. Indian people and Christian groups) at the site, thus showing the multicultural and multireligious character of al-Balīd.

\section{About the Author}

Agnese Fusaro holds a PhD in Islamic archaeology, with a specialization in ceramics. She is a member of the ERAAUB team (University of Barcelona). She has participated and currently participates in many archaeological projects in Syria, Iran, Iraqi Kurdistan, Pakistan, Oman, Uzbekistan. She has work experience in the museum field and in academic teaching.

\section{References}

Al Baleed Archaeological Park Salalah (2014). Muscat: Office of the Adviser to His Majesty the Sultan for Cultural Affairs Sultanate of Oman.

Albright, F.P. (1982). The American archaeological expedition in Dhofar, Oman, 1952-1953. Washington DC: American Foundation for the Study of Man.

Almamari, B.M. (2017). Imported Traditional Pottery: Methods of Overcoming the Challenges for Traditional Ceramics Industries in Oman. Humanities and Social Sciences 5 (1), pp. 1-4.

Beckingham, C.F., and Serjeant, R.B. (1950). A Journey by Two Jesuits from Dhufār to San'ā in 1590. The Geographical Journal 115 (4/6), pp. 194-207.

Carter, R. (2013). Christianity in the Gulf after the coming of Islam: redating the Churches and Monasteries of Bet Qatraye. In: C.J. Robin and J. Schiettecatte, eds., Les preludes de l'Islam. Ruptures et continuités dans les civilisations du Proche-Orient, de l'Afrique orientale, de l'Arabie et de l'Inde à la veille de l'Islam, Paris: De Boccard, pp. 311-330.

Carvajal López, J.C., Giobbe, M., Adeyemo, E., Georgakopoulou, M., Carter, R., Sakal, F., Bianchi, A., and Al-Na'ìmī, F. (2019). Production and provenance of Gulf wares unearthed in the Old Doha Rescue Excavations Project. Proceedings of the Seminar for Arabian Studies 49, pp. 51-68.

Chittick, N. (1974). Kilwa. An Islamic trading city on the East African coast. Nairobi: British Institute in Eastern Africa. 
Chittick, N. (1984). Manda. Excavations at an island port on the Kenya coast. Nairobi: British Institute in Eastern Africa.

Ciuk, C., and Keall, E. (1996). Zabid Project Pottery Manual 1995. Pre-Islamic and Islamic Ceramics from the Zabid area, North Yemen. Oxford: Tempvs Reparatvm.

Collinet, A. (2015). III/2-4. Les céramiques de l'Inde et du Sind. In: A. Rougeulle, ed., Sharma. Un entrepôt de commerce medieval sur la côte du Haḍramawt (Yémen, ca 980-1180), Oxford: Archaeopress, pp. $165^{-167}$.

Costa, P. (1979). The study of the city of Zafar (al-Balīd).Journal of Oman Studies 5, pp. 111-150.

Crowe, Y. (2002). Persia and China. Safavid Blue and White Ceramics in the Victoria and Albert Museum 1501-1738. London: La Borie.

David-Cluny, H. (2001). Soft stone mining evidence in the Oman Peninsula and its relation to Mesopotamia. In: S. Cleziou, M. Tosi, and J. Zarins, eds., Essays on the late prehistory of the Arabian Peninsula. Serie Orientale Roma XCIII, Rome: Istituto italiano per l'Africa e l'Oriente, pp. 317-335.

David-Weill, J. (1960). Sur un bol de Damas. Cahiers de la Céramique, du Verre et des Arts du Feu 19 , pp. $183^{-184 .}$

Defremery, C., and Sanguinetti, B.R. (1969, first ed. 1854). Voyages d'Ibn Battûta, texte arabe, accompagné d'une traduction, Volume 2. Paris: éditions anthropos paris.

Ettinghausen, R. (1965). The Uses of Sphero-Conical Vessels in the Muslim East. Journal of Near Eastern Studies 24 (3), Erich F. Schmidt Memorial Issue. Part One, pp. 218-229.

Floor, W. (2017). Omani-Portuguese Maritime Activities (1500-1650 CE). In: A. Al Salimi and E. Staples, eds., Studies on Ibadism and Oman, Oman. A Maritime History, Volume 9, Hildesheim - Zürich - New York: Georg Olms Verlag, pp. 117-137.

François, V. (1999). Céramiques médiévales à Alexandrie, Contribution à l'histoire économique de la ville. Cairo: Institut français d'archéologie orientale.

Franke-Vogt, U. (2002). Remarks on the Classification of the Pottery from Al-Balid, Dhofar (Oman). Unpublished ms., Bonn.

Frifelt, K., with contributions by P. Bangsgaard and V. Porter (2001). Islamic Remains in Bahrain. Jutland Archaeological Society Publications Volume 37. Højbjerg: Jutland Archeological Society in association with Moesgaard Museum and Ministry of Information, State of Bahrain.

Fusaro, A. (2019). New project on Islamic ceramics from al-Balīd: chronology, technology, tradition, and provenance. Proceedings of the Seminar for Arabian Studies 49, pp. 129-146.

Gomis, O. (2011). The Cross of Anuradhapura. Daily News. Sri Lanka's National Newspaper Since 1918, April 22 http://archives.dailynews.lk/2011/o4/22/fea32.asp.

González-Ruibal, A., de Torres, J., Franco, M.A., Abdi Ali, M., Mohamed Shabelle, A., Martínez Barrio, C., and Ahmed Aideed, K. (2017). Exploring long distance trade in Somaliland (AD 1000-1900): preliminary results from the 2015-2016 field seasons. Azania:Archaeological Research in Africa $5^{2}$ (2), pp. 135-172.

Guest, R. (1935). Zufar in the Middle Ages. Islamic Culture 9, pp. 402-410.

Hansman, J. (1985). Julfär, an Arabian Port. Its Settlement and Far Eastern Ceramic Trade from the 14th to the 18th Centuries. London: Royal Asiatic Society of Great Britain and Ireland.

Hardy-Guilbert, C. (2005). La "mustard ware" yéménite, un marqueur chronologique du $\mathrm{XIV}^{\mathrm{e}}$ siècle. Taoci 4. Actes du colloque Chine-Méditerranée. Routes et échanges de la céramique avant le XVI ${ }^{e}$ siècle, Paris: Société Française d'Etude de la Céramique Orientale, Musée Cernuschi, pp. 117-125.

Hardy-Guilbert, C., and Rougeulle, A. (1995). Archaeological Research into the Islamic Period in Yemen: Preliminary Notes on the French Expedition, 1993. Proceedings of the Seminar for Arabian Studies 25, pp. 29-44.

Horton, M. (1996). Shanga: the archaeology of a Muslim trading community on the coast of East Africa. London: British Institute in Eastern Africa. 
Jansen, M., ed. (2015). The Archaeological Park of Al-Baleed, Sultanate of Oman. Site Atlas along with selected Technical Reports 1995-2001. Muscat: Office of the Adviser to His Majesty the Sultan for Cultural Affairs.

Jenkins, M. (1984). Mamluk Underglaze-Painted Pottery: Foundations for Future Study. Muqarnas 2, The Art of Mamluks, pp. 95-114.

Keall, E.J. (1983). The Dynamics of Zabid and Its Hinterland: The Survey of a Town on the Tihamah Plain of North Yemen. World Archaeology 14 (3), pp. 378-392.

Keall, E.J. (1991). Drastic Changes in 16th century Zabid. Proceedings of the Seminar for Arabian Studies 21, pp. 79-96.

Keall, E.J. (1992). Smokers' Pipes and the Fine Pottery Tradition of Hays. Proceedings of the Seminar for Arabian Studies 22, pp. 29-46.

Kennet, D. (2004). Sasanian and Islamic Pottery from Ras al Khaimah. Classification, Chronology and Analysis of Trade in the Western Indian Ocean. Oxford: Archaeopress.

Kervran, M. (1996). Indian Ceramics in Southern Iran and Eastern Arabia. Repertory, Classification and Chronology. In: H.P. Ray and J.-F. Salles, eds., Tradition and Archaeology, Early Maritime Contacts in the Indian Ocean. Proceedings of the International Seminar TechnoArchaeological Perspectives of Seafaring in the Indian Ocean 4th cent. BC-15th cent. A.D. New Delhi, February 28-March 4, 1994, New Delhi - Lyon: Manohar, pp. 37-58.

Malekandathil, P. (2017). Contextualizing the Encounters between Portuguese Missionaries and the St. Thomas Christians. Thomas Christian Heritage:Journal of the Syro-Malabar Liturgical Centre X (18), pp. 61-109.

Mitsuishi, G., and Kennet, D., with contributions from J. Szuchman and R. Hawker (2013). Kiln sites of the fourteenth-twentieth-century Julfar ware pottery industry in Ras al-Khaimah, UAE. Proceedings of the Seminar for Arabian Studies 43, pp. 1-14.

Moffett, S.H. (2005). A History of Christianity in Asia, Volume II, 1500-1900. New York: Orbis Books.

Monchamp, J. (2016). Sphero-conical Vessels from the Ayyubid Wall in Cairo: A Typology (11th15th c.). Journal of Islamic Archaeology 3 (2), pp. 195-207.

Nanji, R.J. (2011). Mariners and Merchants: A Study of the Ceramics from Sanjan (Gujarat). BAR International Series 2231. Oxford: Archaeopress.

Newton, L.S., and Zarins, Y. (2010). Preliminary results of the Dhofar archaeological survey. Proceedings of the Seminar for Arabian Studies 40, pp. 247-265.

Newton, L.S., and Zarins, J. (2014). A possible Indian quarter at al-Baleed in the fourteenthseventeenth centuries AD?. Proceedings of the Seminar for Arabian Studies 44, pp. 257-276.

Newton, L., and Zarins, J. (2017). Dhofar through the Ages. An Archaeological, Ecological and Historical Landscape. Muscat: Ministry of Heritage and Culture.

Nicolini, B. (2017). Oman's Maritime Activities throughout the Indian Ocean: 1650-1856 CE. In: A. Al Salimi and E. Staples, eds., Studies on Ibadism and Oman, Oman. A Maritime History, Volume 9, Hildesheim - Zürich - New York: Georg Olms Verlag, pp. 141-159.

Pavan, A. (2017). A Cosmopolitan City on the Arabian Coast. The imported and local pottery from Khor Rori. Khor Rori Report 3, Arabia Antica 12. Rome: 'L'Erma' di Bretschneider.

Pavan, A., Fusaro, A., Visconti, C., Ghidoni, A., and Annucci, A. (2018). Archaeological Works at the Fortified Castle of Al Baleed (Husn Al Baleed), Southern Oman: Preliminary Results from the Fieldwork and the Study of the Materials. Egitto e Vicino Oriente XLI, pp. 211-234.

Pavan, A., and Visconti, C. (2O2O). Trade and contacts between Southern Arabia and East Asia: the evidence from al-Balīd (southern Oman). Proceedings of the Seminar for Arabian Studies 50, pp. $243^{-257}$.

Peterson, B. (1980). Blue and white imitation pottery from the Ghaibi and related workshops in Mediaeval Cairo. The Museum of Far Eastern Antiquities 52, pp. 65-88.

Peterson, J.E. (2004). Oman's Diverse Society: Southern Oman. Middle East Journal $5^{8}$ (2), pp. 254-269. 
Porter, A. (2018). The distribution and provenance of ancient South Arabian steatite-tempered pottery: a thin-section analysis. In: C.S. Phillips and St J. Simpson, eds., Softstone. Approaches to the study of chlorite and calcite vessels in the Middle East and Central Asia from prehistory to the present, Oxford: Archaeopress, pp. 137-166.

Power, T. (2015). A first ceramic chronology for the late Islamic Arabian Gulf. Journal of Islamic Archaeology 2 (1), pp. 1-33.

Power, T. (2017). Julfar and the Ports of Northern Oman. In: A. Al Salimi and E. Staples, eds., Studies on Ibadism and Oman, Ports of Oman, Volume 10, Hildesheim - Zürich - New York: Georg Olms Verlag, pp. 215-240.

Pradines, P. (2010). Gedi, une cité portuaire swahilie. Islam médiéval en Afrique orientale. Monographies d'archéologie islamique, IFAO: Cairo, 222-224 \& 259-261.

Priestman, S.M.N. (2005). Settlement \& ceramics in Southern Iran: An analysis of the Sasanian \& Islamic periods in the Williamson collection, MA Thesis, Department of Archeology, Durham University. http://etheses.dur.ac.uk/2745/.

Priestman, S.M.N. (2008). Chapter Nine. Islamic pottery in Oman. In: A. al-Salimi, H. Gaube, and L. Korn, eds., Islamic art in Oman, Muscat: Mazoon Printing, pp. 26o-281.

Reddy, A.L. (2016). Archaeology of Indo-Gulf Relations in the Early Historic Period: The Ceramic Evidence. In: H.P. Ray, ed., Bridging the Gulf. Maritime Cultural Heritage of the Western Indian Ocean, New Delhi: Manohar, pp. 53-78.

Richardson, N., and Dorr, M. (2003). The Craft Heritage of Oman, Volume 2. Dubai: Motivate Publishing.

Rollinson, H. (2017). Masirah - the other Oman ophiolite: A better analogue for mid-ocean ridge processes?. Geoscience Frontiers 8, pp. 1253-1262.

Rougeulle, A. (2007). Ceramic production in medieval Yemen: the Yadhghat kiln site. Proceedings of the Seminar for Arabian Studies 37, pp. 239-252.

Rougeulle, A. (2008). A Medieval Trade Entrepôt at Khor Rori? The Study of the Islamic Ceramics from al-Hamr al-Sharqiya. In: A. Avanzini, ed., A Port in Arabia between Rome and the Indian Ocean (3rd C. BC-5th C. AD). Khor Rori Report 2, Arabia Antica Series, Rome: 'L'Erma' di Bretschneider, pp. $645^{-667 .}$

Rougeulle, A. (2015). Sharma. Un entrepôt de commerce medieval sur la côte du Hadramawt (Yémen, ca 980-1180). Oxford: Archaeopress.

Rougeulle, A., Renel, H., Simsek, G., and Colomban, P. (2014). Medieval ceramic production at Qalhāt, Oman, a multidisciplinary approach. Proceedings of the Seminar for Arabian Studies 44, pp. 299-316.

Al Salimi, A., and Staples, E., eds. (2017a). Studies on Ibadism and Oman, Oman. A Maritime History, Volume 9. Hildesheim - Zürich - New York: Georg Olms Verlag.

Al Salimi, A., and Staples, E., eds. (2017b). Studies on Ibadism and Oman, Ports of Oman, Volume 1 . Hildesheim - Zürich - New York: Georg Olms Verlag.

Saunders, B.J.O. (2013). The trade and distribution of ceramics in the Western Indian Ocean $1250-$ 1550 AD. An analysis of current available assemblages from Arabia, Iran and East Africa, MRes Thesis, Department of Archaeology, Durham University. http://etheses.dur.ac.uk/7316/.

Scanlon, G.T. (1984). Mamluk Pottery: More Evidence from Fustat. Muqarnas 2, The Art of Mamluks, pp. 115-126.

Schenk, H. (2014). Tissamaharama Pottery sequence and the Early Historic maritime Silk Route across the Indian Ocean. Zeitschrift fürArchäologie Außereuropäischer Kulturen 6, pp. 95-117.

Sedov, A.V., and Benvenuti, C. (2002). The pottery of Sumhuram: general typology. In: A. Avanzini, ed., Khor Rori Report 1, Pisa: Edizioni Plus, pp. 177-199.

Selvakumar, V. (2011). 9. Contacts between India and Southeast Asia in Ceramic and Boat Building Traditions. In: P.-Y. Manguin, A. Mani, and G. Wade, eds., Early Interactions Between South and Southeast Asia. Reflections on Cross-Cultural Exchange, Singapore: ISEAS Publishing, pp. $197^{-220 .}$ 
Serjeant, R.B. (1959). Notes and Communications. Saint Sergius. Bulletin of the School of Oriental and African Studies, University of London 22 (1/3), pp. 574-575.

Sikdar, M., and Chauduri, P. (2015). Pottery making tradition among the Prajapati community of Gujarat, India. Eurasian Journal of Anthropology 6 (1), pp. 1-14.

Smith, G.R. (1985). Ibn Al-Mujāwir on Dhofar and Socotra. Proceedings of the Seminar for Arabian Studies 15, pp. 79-92.

Smith, G.R. (1988). The Rasulids in Dhofar in the VIIth-VIIIth/XIIIth-XIVth centuries. Journal of the Royal Asiatic Society 120 (1), pp. 26-44.

Smith, G.R. (2005). Zafār. In: P.J. Bearman, Th. Bianquis, C.E. Bosworth, E. van Donzel, and W.P. Heinrichs, eds., Encyclopédie de l'Islam, Volume XI, Leiden: Brill, pp. 412-413.

Smith, G.R. (2007). Kathīrī. In: P.J. Bearman, Th. Bianquis, C.E. Bosworth, E. van Donzel, and W.P. Heinrichs, eds., Encyclopaedie de l'Islam, Nouvelle édition, Volume XII, Leiden: Brill, pp. 522-523.

Smith, L.M.V., Mallinson, M.D.S., Phillips, J.S., Adam, A.H., Said, A.I., Barnard, H., Breen, C.P., Britton, D., Forsythe, W., Jansen van Rensburg, J., McErlean, T., and Porter, S. (2012). Archaeology and the Archaeological and Historical Evidence for the Trade of Suakin, Sudan. In: D.A. Agius, J.P. Cooper, A. Trakadas, and C. Zazzaro, eds., Navigated spaces, connected places: Proceedings of Red Sea Project V, Oxford: Archaeopress, pp. 173-186.

Staples, E. (2017). Oman and Islamic Maritime Networks:630-1507 CE. In: A. Al Salimi and E. Staples, eds., Studies on Ibadism and Oman, Oman. A Maritime History, Volume 9, Hildesheim - Zürich - New York: Georg Olms Verlag, pp. 81-115.

Stern, E.J., with contributions by A. Shapiro and S.Y. Waksman (2012). 'Akko I. The 1991-1998 Excavations. The Crusader-Period Pottery. Jerusalem: The Israel Antiquities Authority.

Tkatsch, J. (1934). Zafār. 4. In: M.Th. Houtsma, A.J. Wensinck, E. Lévi-Provençal, H.A.R. Gibb, and W. Heffening, eds., Encyclopédie de l'Islam, Volume IV, Leiden and Paris: Brill and C. Klincksieck, pp. 1253-1257.

Tomber, R., Cartwright, C., and Gupta, S. (2011). Rice temper: Technological solution and source identification in the Indian Ocean. Journal of Archaeological Science 38, pp. 36o-366.

Tonghini, C. (1998). Qal'at Jabar Pottery: A Study of a Syrian Fortified Site of the Late XIXIV Century. Oxford: Oxford University Press.

Varisco, D.M. (1993). Texts and Pretexts: The Unity of the Rasulid State under al-Malik al-Muzaffar. Revue du monde musulman et de la Méditerranée 67, pp. 13-24.

Vezzoli, V. (2011). The Fustat Ceramic Collection in the Royal Museums of Art and History in Brussels: the Mamluk Assemblage. Bulletin des Musées Royaux d'Art et d'Histoire Parc du Cinquantenaire Bruxelles 82, pp. 119-168.

Watson, O. (2004). Ceramics from Islamic Lands. London: Thames \& Hudson.

Whitcomb, D.S., and Johnson, J.H. (1982). Quseir al-Qadim 1980. Preliminary Report. Malibu: Undena Publications.

Yule, P., and Mohammad, K.K. [1998] (2006). Report on Al-Baleed Pottery: Reference Collection. RWTH Aachen University, Muscat: Office of the Advisor to HM the Sultan for Cultural Affairs.

Zarins, J., and Newton, L. (2012). Al Baleed: ancient Zafar, Sultanate of Oman. Report of 236 excavations, 2005-2011 and Salalah Survey. Unpublished ms., Muscat.

Zarins, J., and Newton, L. (2017a). Northern Indian Ocean Islamic Seaports and the Interior of the Arabian Peninsula. In: A. Al Salimi and E. Staples, eds., Studies on Ibadism and Oman, Ports of Oman, Volume 10, Hildesheim - Zürich - New York: Georg Olms Verlag, pp. 57-87.

Zarins, J., and Newton, L. (2017b). Islamic Period Maritime Trade and Travel along the Southern Arabian Coasts of the Indian Ocean: The Case of Socotra, the Hallaniyat, Masirah and Mahut Islands. In: A. Al Salimi and E. Staples, eds., Studies on Ibadism and Oman, Ports of Oman, Volume 10, Hildesheim - Zürich - New York: Georg Olms Verlag, pp. 89-115.

Živković, J., Power, T., Georgakopoulou, M., and Carvajal López, J.C. (2019). Defining new technological traditions of Late Islamic Arabia: a view on Bahlā Ware from al-Ain (UAE) and the lead-barium glaze production. Archaeological and Anthropological Sciences 11, pp. 4697-4709. 


\section{Notes}

$1 \quad$ This is a revised version of a paper presented at the International Conference "Muslim Cultures in the Indian Ocean. Diversity and Pluralism, Past \& Present" held at the Institute for the Study of Muslim Civilisations, The Aga Khan University, London, 12-14 September 2018.

2 Many thanks to the Omani Office of the Adviser to His Majesty the Sultan for Cultural Affairs, that has given me permission to carry out this research work. My sincere gratitude to Alexia Pavan, the staff of the Museum of the Frankincense Land, and the Dhofari women potters who shared with me their experience and knowledge.

For the years 2017-18, this project has been funded by the Max van Berchem Foundation, established in 1973 in memory of Max van Berchem (1863-1921), the founder of Arabic epigraphy. Based in Geneva, the aim of the Foundation is to promote the study of Islamic and Arabic archaeology, history, geography, art, epigraphy, religion and literature.

3 The palace of the 'sultan of Zafāar' was named 'Alhisn' (castle) at the time of Ibn Battuntata (Defremery and Sanguinetti, 1969: 212).

4 The expedition of the American Foundation for the Study of Man, led by Wendell Phillips and Frank Albright, since $195^{2}$ (Albright, 1982); the work of Paolo Costa, that is particularly worth mentioning (Costa, 1979); the project for the set-up of an archaeological park and the identification of the main landmarks of the site by Michael Jansen (RWTH Aachen University), within the framework of UNESCO, between 1996 and 2003 (Jansen, 2015); the American archaeological mission led by Juris Zarins (Missouri State University) and Lynne Newton (University of Minnesota), from 2005 to 2012 (Zarins and Newton, 2012; Newton and Zarins, 2017).

5 In parallel, since 2013, a small archaeological team of the University of Arkansas at Little Rock, led by Krista Lewis, investigated a residential compound in the south-western area of the site.

6 Fusaro, 2019. Previous research on the pottery from the site was conducted by Paul Yule and K.K. Mohammad (Yule and Mohammad, 2006), Ute Franke-Vogt (Franke-Vogt, 2002), Lynne Newton and Juris Zarins (Zarins and Newton, 2012).

7 The excavated layers from which the ceramics were collected and the related chronological phases are presented in Fusaro, 2019: 143-144, fig. 10.

8 These phases cover a time ranging from the end of the thirteenth to the end of the eighteenth century.

9 See also Newton and Zarins, 2010: 248, 258.

10 Very similar characteristics have been noted in Dhofari modern pottery production by the same author and by previous scholars, see Richardson and Dorr, 2003: 503-507.

11 Richardson and Dorr reported the use of the motif on the Dhofari pottery until the end of the twentieth and the beginning of the twenty-first century (Richardson and Dorr, 2003: 46-47, 74, 78-81). Nowadays it is lost, as the women potters we interviewed could not recognise the motif on ancient vessels.

12 This process seems to have started in recent years; indeed, between 2000 and 2010, researchers working on modern pottery production of Oman still noticed different clay sources, some also in the coastal area, as well as a variety of forms and techniques that almost do not exist anymore (Richardson and Dorr, 2003: 503; Pavan, personal communication).

13 The different provenance areas of the imported items have been identified through the examination of their styles and fabrics, together with a comparative analysis of other coeval ceramic corpora. The study of the Far Eastern imports is currently conducted by Chiara Visconti (Visconti in Pavan et al., 2018; Pavan and Visconti, 2020).

14 The presence of Chinese and Far Eastern ceramics ranges from $0.8 \%$ to $4.4 \%$ in the single stratigraphic units. This quantity is remarkable if we consider that their percentage in assemblages from other Indian Ocean sites is generally below 1\% (Pavan and Visconti, 2020: 247-250).

15 For the decorative pattern of the item displayed in Fig. 12, see also cat.no. 29/1988 kept in the David Collection, Copenaghen.

16 In general, there is little archaeological evidence of Omani presence in East Africa and at the reverse (Staples, 2017: 101).

17 For similar items, see Crowe, 2002: form 139, p. 105, form 148, p. 106; cat.nos. 149 and 155, pp. 117, 119, dated to the mid-seventeenth century.

18 For similar items, see Crowe, 2002: cat.nos. 72, 89, 222, pp. 82, 90, 144, dated to the seventeenth century; Watson, 2004: cat.no. U.19, p. 466 dated to the seventeenth century.

19 Even if this ware widely circulated in the Arabian Peninsula and the Gulf area during the late Islamic period, it has received little attention. Along with a few more comprehensive studies recently published on the topic (Priestman, 2008; Rougeulle et al., 2014; Živković et al., 2019; Carvajal López et al. 
2019: 59, 63), the ongoing research work could provide useful data to characterise better the Bahla/ Khunj production.

Alternatively they could be also identified as South Iranian products (Hansman, 1985: 54-55).

Similar items have also been identified from Zabīd (Ciuk and Keall, 1996: pl. 95/46, j-m, pl. 95/48, j-l).

They are covered with transparent green and/or yellow glaze, with a simple carved decoration on the exterior.

This kind of decoration is not common among those used for local wares.

Rougeulle, 2007: small bowl of fig. 3/21, large bowls displayed as fig. 9/10-12, pot with piercing holes of the fig. 9/18; for example, they can be compared with the local vessels of the grit temper ware displayed as Fig.4.

It belongs to a group of a few unglazed vessels made from a peculiar coarse dark red fabric, with black angular and white inclusions. They have been interpreted as items possibly coming from the Gulf area; nonetheless, we cannot not exclude that they may come from the southern Iranian regions, as the author personally classified and analysed vessels with similar fabric features collected in Fars.

Josefina Pérez Arantegui, Instituto Universitario de Investigación en Ciencias Ambientales de Aragón.

For similar items, see the third type of so-called micaceous ware identified at al-Hamr al-Sharqiya (Rougeulle, 2008: 653-654).

An almost identical item was found in the surface layer of Qal'at al-Bahrain (Frifelt, 2001: 102-104, fig. 184).

With regard to this interpretation, see also Ettinghausen, 1965: 224.

Their hypothesis was supported both by the presence of Indian vessels found throughout their excavation campaigns at the site (Newton and Zarins, 2014: 267; Zarins and Newton, 2012: 117-120), and by the discovery of a trapezoidal building dated to the thirteenth and seventeenth centuries and interpreted as a religious complex possibly related to an Indian community (Newton and Zarins, 2014: 266).

Some of these items show interesting similarities with pottery from Tissamaharama, see Schenk, 2014 .

For specific comparisons with the displayed items, see Nanji, 2011: cat.nos. T.9o, T.92, T.92.2, T.93, T.147; Chittick, 1984: 101, fig. 54.f.

The main temper added to the clay in modern traditional pottery productions in Gujarat is vegetal material (Sikdar and Chauduri, 2015: 8, in this case it is saw dust).

Several sites, such as Lahori Bandar and Mullah Kay Kot, were personally visited by the author in 2018-19.

5 The motif also resembles the so-called Anuradhapura cross, associated with the presence of a Nestorian community or a group of Saint Thomas Christians in Sri Lanka (Gomis, 2011). 